\title{
Morphological identification of ticks and molecular detection of tick-borne pathogens from bare-nosed wombats (Vombatus ursinus)
}

\author{
Danielle Beard ${ }^{1}$, Hayley J. Stannard ${ }^{2}$ and Julie M. Old ${ }^{1 *}$ (D)
}

\begin{abstract}
Background: Ticks are obligate haematophagous ectoparasites of vertebrate hosts and transmit the widest range of pathogenic organisms of any arthropod vector. Seven tick species are known to feed on bare-nosed wombats (Vombatus ursinus), in addition to the highly prevalent Sarcoptes scabiei mite which causes fatal sarcoptic mange in most bare-nosed wombat populations. Little is known about the pathogens carried by most wombat ticks or how they may impact wombats and wombat handlers.
\end{abstract}

Methods: Wombat ticks were sourced from wild life hospitals and sanctuaries across Australia and identified to species level using taxonomic keys. Genomic DNA was extracted from a subsample, and following the amplification of the bacterial 16S rRNA gene V3-V4 hypervariable region, next-generation sequencing (NGS) on the Illumina MiSeq platform was used to assess the microbial composition.

Results: A total of 447 tick specimens were collected from 47 bare-nosed wombats between January 2019 and January 2020. Five species of ticks were identified comprising wombat tick Bothriocroton auruginans $(n=420)$, wallaby tick Haemaphysalis bancrofti $(n=8)$, bush tick Haemaphysalis longicornis $(n=3)$, common marsupial tick Ixodes tasmani $(n$ $=12)$, and Australian paralysis tick /xodes holocyclus $(n=4)$. Tick infestations ranged from one to 73 ticks per wombat. The wombat tick was the most prevalent tick species comprising $94 \%$ of the total number of samples and was present on 97.9\% (46/47) of wombat hosts. NGS results revealed the $16 \mathrm{~S}$ rRNA gene diversity profile was predominantly Proteobacteria (55.1\%) followed by Firmicutes (21.9\%) and Actinobacteria (18.4\%). A species of Coxiella sharing closest sequence identity to Coxiella burnetii (99.07\%), was detected in $72 \%$ of B. auruginans and a Rickettsiella endosymbiont dominated the bacterial profile for I. tasmani.

Conclusions: A new host record for $\mathrm{H}$. longicornis is the bare-nosed wombat. One adult male and two engorged adult female specimens were found on an adult male wombat from Coolagolite in New South Wales, and more specimens should be collected to confirm this host record. The most prevalent tick found on bare-nosed wombats was B. auruginans, confirming previous records. Analysis of alpha-diversity showed high variability across both sample locations and instars, similar to previous studies. The detection of various Proteobacteria in this study highlights the high bacterial diversity in native Australian ticks.

Keywords: Wombat, Tick, Microbiome, Marsupial, $16 \mathrm{~S}$ ribosomal RNA gene, Next-generation sequencing, Bacteria

*Correspondence: J.old@westernsydney.edu.au

${ }^{1}$ School of Science, Western Sydney University, Penrith, New South Wales, Australia

Full list of author information is available at the end of the article

(c) The Author(s) 2021. This article is licensed under a Creative Commons Attribution 4.0 International License, which permits use, sharing, adaptation, distribution and reproduction in any medium or format, as long as you give appropriate credit to the original author(s) and the source, provide a link to the Creative Commons licence, and indicate if changes were made. The images or other third party material in this article are included in the article's Creative Commons licence, unless indicated otherwise in a credit line to the material. If material is not included in the article's Creative Commons licence and your intended use is not permitted by statutory regulation or exceeds the permitted use, you will need to obtain permission directly from the copyright holder. To view a copy of this licence, visit http://creativeco mmons.org/licenses/by/4.0/. The Creative Commons Public Domain Dedication waiver (http://creativecommons.org/publicdomain/ zero/1.0/) applies to the data made available in this article, unless otherwise stated in a credit line to the data. 


\section{Background}

Ticks (Acari: Ixodidae) are obligate ectoparasitic arachnids that are classified into three families: Ixodidae (hard ticks), Argasidae (soft ticks), and Nuttalliellidae. Each of the three families have evolved unique biological, physiological and ecological disparities which have resulted in different abilities and capacities to transmit pathogens [1]. However, ticks can transmit the widest range of pathogens of any arthropod vector and are the primary cause of vector-borne diseases in livestock and domestic animals [2]. Ixodids transmit the widest number of pathogens worldwide and are responsible for the majority of tick-borne infections [3].

In addition to pathogens, the tick microbiome comprises a community of commensal and symbiotic obligate endosymbionts which make up the majority of the tick microbiome and reside both inside and outside the body of ticks [4]. The effect of these organisms has been somewhat neglected in studies, but may present various detrimental, neutral, or beneficial effects to their tick hosts, and also contribute to driving the transmission of tick-borne pathogens [5]. Non-pathogenic microorganisms are typically transovarially transmitted [6] and may impact tick growth, reproduction, fitness, nutritive adaptation and defence against environmental stresses [7, 8]. The functional roles of tick microorganisms and their relationships may provide further insights into the pathogenicity and evolution of tick pathogens. For example, it has become increasingly clear since the advancement of molecular barcoding techniques that many species of Rickettsia, Francisella, and Coxiella, which are generally considered pathogens of medical and veterinary importance, have evolved as non-pathogenic endosymbionts of ticks [9].

While tick-borne bacteria have been relatively well studied in the northern hemisphere, very little is known about the presence or diversity of bacteria in Australian ticks [10]. The microbiome and pathogenicity of Australian ticks are unique when compared to other species, and so is the response to ticks and tick-borne pathogens from native vertebrate hosts [11]. Recently, unique Australian species of Anaplasma, Ehrlichia and Neoehrlichia [12, 13 ] and the first native Borrelia species were characterised in native ticks [14]. Other novel microbial species have also been reported in Australian ticks [12, 15, 16]; however, the focus has largely been on ticks of human, domestic animal and livestock importance, and few studies have surveyed ticks associated with wildlife $[17,18]$.

Bare-nosed wombat (Vombatus ursinus) populations are significantly impacted by the ectoparasite Sarcoptes scabiei, which causes sarcoptic mange [19]; however, little is known about other wombat ectoparasites or their associated pathogens. Australian fauna have co-evolved with native tick species, and healthy wombats regularly carry large burdens of ticks which would otherwise affect humans and domestic animals [20]. However, wombats affected by sarcoptic mange, orphaned or injured wombats released from captivity and wombats raised in a comparatively parasite-free captive environment before release are likely at an increased risk of contracting tickborne diseases. Managing wild species in captivity may induce stress, impair immunity and expose hosts to novel parasites to which the immune system is naïve [21]. Population density is also often atypical in captivity, which may result in higher than usual parasite burdens. Additionally, the use of anti-parasitic medications on captive animals affects both host-parasite relationships and individuals, as the latter are at an increased risk of disease once released, having not developed acquired immunity [22].

Seven species of ticks have previously been recorded feeding on bare-nosed wombats including the wombat tick Bothriocroton auruginans [23][23], wallaby tick Haemaphysalis bancrofti [24], Australian paralysis tick Ixodes holocyclus [25], Tasmanian paralysis tick Ixodes cornuatus [26], Ixodes phascolomyis [27], common marsupial tick Ixodes tasmani and Ixodes victoriensis [28] [28]. The relationship between S. scabiei and other known wombat ectoparasites, their pathogens, ability to co-infect hosts, and their overall impact on wombat hosts have not yet been investigated. There is also very little known about the life cycles of wombat ectoparasites and their level of host specificity. Coxiella burnetii has been found in B. auruginans collected from bare-nosed wombats, as well as a Rickettsia species closely related to Rickettsia massiliae, which causes human disease [29]. These are the only pathogens that have been detected in ticks taken from wombat hosts, and were identified using specific targeted methods.

The development of next-generation sequencing (NGS) technologies has enabled the microbial communities of ticks to be explored in a fast and cost-efficient manner [15]; however, very little is known about the microbiome of native Australian ticks [10] and no studies have focused on wombat ticks or tick-borne pathogens. Bare-nosed wombats are already significantly affected by a known ectoparasite, so it would be beneficial to understand the other parasitic and pathogenic threats that wombats may need to overcome simultaneous to or following the treatment of sarcoptic mange. It is also important to identify potential zoonotic threats to wombat handlers and domestic animals that may come into contact with wombats or their burrows. This study aimed to identify the species of ticks associated with bare-nosed wombats and to use NGS and metabarcoding to investigate the bacterial diversity associated with these ticks. 


\section{Methods}

Tick collection and identification

All ticks were collected directly from wombat hosts between January 2019 and January 2020 throughout eastern Australia (Fig. 1) including from live animals being rehabilitated for release, as well as opportunistic collections from road-killed wombats, and placed into $70 \%$ ethanol. The location where the ticks were collected, the date, and habitat type for the wombat hosts were recorded. Temperature and rainfall were obtained from the Bureau of Meteorology for the date and Global Positioning System coordinates where ticks were submitted. All ticks were identified morphologically to species and life stage using existing taxonomic keys [30, 31] and a Nikon SMZ445 stereomicroscope. Species, sex and instar were recorded for each specimen except for two nymphal specimens and specimens that were damaged during removal. There is a lack of detailed morphological keys for some Australian native ticks at the larval and nymphal stages [32], so some of these specimens could only be identified to genus level. Damaged ticks were identified to instar and genus. Photographs of tick specimens were taken using an Olympus DP72 stereomicroscope with an external Euromex EK-1 fibre optic light source and cellSens Standard version 1.5 software. Ticks were stored in sterile tubes containing $70 \%$ ethanol between identification and molecular analysis.

\section{Sample mapping}

The locations of tick sample collection were geo-referenced using the open source software QGIS version 3.12.1 [33] with the latest Australian coordinate system Geocentric Datum of Australia 2020 incorporated through the ICSM NTv2 Transformer plugin [34]. Layers were styled with a categorised renderer and layer symbology was characterised according to tick species. To visualise overlapping points, a point displacement renderer was used around a centre symbol on rendering circles for tick distribution, and a point cluster renderer was used to visualise overlying pathogen distribution [35].

\section{Molecular methods}

Samples were sent to the Australian Genome Research Facility in Urrbrae, Adelaide Australia. DNA was extracted using the DNeasy PowerSoil Pro DNA Extraction Kit (Qiagen, Venlo, the Netherlands) according to the manufacturer's instructions. A total of 79 whole tick specimens were then sequenced on an Illumina MiSeq platform [36]. Based on previous studies [37], the presence of bacteria in tick samples was detected using the primer pair 341F (5'-CCTAYGGGRBGCASCAG-3') and 806R (5'-GGACTACNNGGGTATCTAAT-3') to amplify the V3-V4 region of the $16 \mathrm{~S}$ rRNA gene, generating a 300-base pair fragment.

The bioinformatics analysis involved demultiplexing, quality control, operational taxonomic unit (OTU) clustering, and taxonomic classification. Image analysis was performed in real time using MiSeq Control Software version 2.6.2.1 and Real Time Analysis version 1.18.54 (Illumina, San Diego, CA), running on the instrument computer. Then the Illumina bcl2fastq 2.20.0.422 pipeline was used to generate the sequence data. Paired-ends reads were assembled by aligning the forward and reverse reads using PEAR version 0.9.5 [38], and primers were identified and trimmed. Trimmed sequences were processed using Quantitative Insights into Microbial Ecology (QIIME) version 1.8.4 [39], USEARCH version 8.0.1623 [40], and UPARSE [41] software. Using USEARCH tools, sequences were then quality filtered, full-length duplicates were removed and sequences were sorted by abundance. Singletons or unique reads were discarded, sequences were clustered and chimeric sequences were filtered using the rdp_gold database as a reference. To obtain the number of reads in each OTU, reads were mapped back to OTUs with a minimum identity of $97 \%$, taxonomy was assigned using QIIME and taxonomies were confirmed using the National Center for Biotechnology Information MegaBLAST. Non-bacterial (eukaryote, unidentified) OTUs were removed and samples with $<100$ assigned OTUs were not considered a positive identification.

\section{Data management and statistical analyses}

Tick collection and identification details were recorded in Microsoft Excel version 2002. Quality assurance was ensured prior to statistical analyses by reviewing all physical data and data entries. Statistical analyses and data visualization were performed using RCommander version 2.6-2 [42], RStudio version 1.2.5033 [43] with the addition of packages vegan version 2.5-6 [44] and phyloseq [45], and Geneious Prime 2020.1.1 (https://www. geneious.com). Alpha-diversity was assessed by richness (inverse Simpson and ACE index) and diversity (Shannon and Simpson index).

\section{Results \\ Tick species}

A total of 447 tick specimens were collected from 47 bare-nosed wombats in New South Wales (NSW) and Tasmania between January 2019 and January 2020 (Table 1). Five species of ticks comprising three genera were morphologically identified (Table 2$)$; wombat tick ( $n$ 


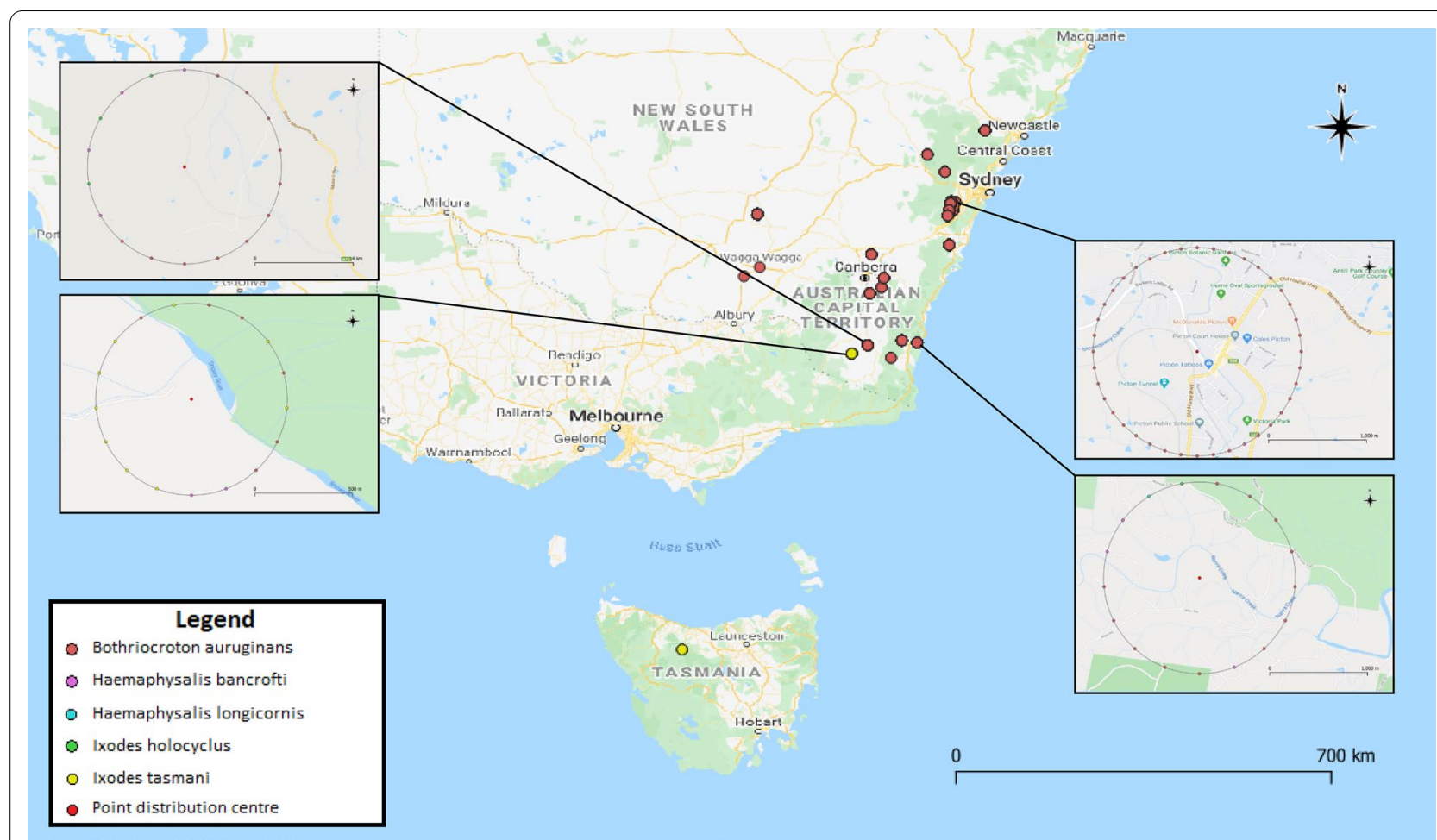

Fig. 1 Geographic distribution of ticks collected from bare-nosed wombat (Vombatus ursinus) hosts between January 2019 and January 2020. Each point represents a unique collection location for the corresponding tick species. Overlapping points were displaced with a point displacement renderer around a centre symbol (denoted in the legend); point displacement distance was defined by number of map units (kilometres)

$=420$; Fig. $2 \mathrm{~d})$, wallaby tick ( $n=8$; Fig. $2 \mathrm{f})$, bush tick $(n$ $=3$; Fig. 2a, e), Australian paralysis tick ( $n=4$; Fig. $2 \mathrm{~b})$, and I. tasmani ( $n=12$; Fig. 2c). Approximate tick infestation ranged from one to 73 ticks per wombat with a total mean infestation of $9.8 \pm 3.9$ ticks per host. Juvenile (joey at foot) wombats exhibited higher mean infestation rates $(25.3 \pm 20.4)$, followed by adult female wombats (7.1 $\pm 4.5)$ and adult male wombats $(6.6 \pm 3.6)$. The wombat tick was the most prevalent tick species comprising $94 \%$ of the total number of samples and was present on 97.9\% (46/47) of wombat hosts. Approximate tick diversity ranged from one to four tick species per wombat. The highest tick diversity was from an adult male wombat in Coolagolite in NSW, an adult male wombat from Dalgety NSW and a wombat of unknown age and sex at Quaama NSW with three tick species identified for each. Females were the most abundant instar identified $(n=164)$, followed by males $(n=129)$, nymphs $(n=115)$, and larvae $(n=39)$. The majority of females $(89 \%)$, nymphs $(96.5 \%)$ and larvae $(100 \%)$ were engorged or semi-engorged from a blood meal (Fig. 3). Larvae could be identified to genus level only. In addition to ticks, there were also incidental collections of nine unidentified fleas and six lice (all of the latter were identified as Boopia tarsata). Most ticks were collected in winter (58\%), followed by spring $(25 \%)$, autumn (6\%) and summer (6\%); the remaining ticks were older specimens for which only the year of collection was recorded.

\section{NGS analysis and bacterial composition of wombat ticks}

A total of 5,890,950 bacterial sequences and 1,759 OTUs (average length 414.3 bases) were assigned; however, only 745 OTUs had greater than 100 total sequences from all tick samples. Ticks had an average of 74,569 assigned sequences each (males 63,397 sequences, females 92,827 sequences, nymphs 56,470 sequences and larvae 57,701 sequences). Engorged females had an average of 99,550 assigned sequences in comparison to unfed females, which had an average of 40,723 sequences. The closest matches for bacterial isolates as determined through GenBank for taxa of interest are shown in Table 3. Proteobacteria comprised the majority of the bacterial phyla composition (55.1\%) followed by Firmicutes $(21.9 \%)$ and Actinobacteria (18.4\%), as shown in Fig. 4. At the genus level Coxiella comprised $40.3 \%$ of the total composition followed by Staphylococcus (13\%). Coxiella was the most dominant genus detected in larvae with a mean prevalence of $81.6 \%$. Nymphs were less likely to be infected with one dominant phyla of bacteria than other instars 
Table 1 Study population of bare-nosed wombats (Vombatus ursinus) used for tick collection in this study

\begin{tabular}{|c|c|c|c|}
\hline Collection location & GPS coordinates & No. of hosts & No. of ticks \\
\hline Cedar Creek, NSW & $32^{\circ} 49^{\prime} 30.32^{\prime \prime} \mathrm{S}, 151^{\circ} 9^{\prime} 2.23^{\prime \prime} \mathrm{E}$ & $7(60,1$ \&) & $32(17$ ठ, 15 o $)$ \\
\hline Rock Flat, NSW & $36^{\circ} 25^{\prime} 34.0284^{\prime \prime} \mathrm{S}, 149^{\circ} 11^{\prime} 2.7132^{\prime \prime} \mathrm{E}$ & $2(10,1 \cup)$ & $18(2 \mathrm{~N}, 16$ o $)$ \\
\hline Bells Line of Road, NSW & $33^{\circ} 31^{\prime} 1.0272^{\prime \prime} \mathrm{S}, 150^{\circ} 28^{\prime} 47.316^{\prime \prime} \mathrm{E}$ & 19 & $5(20,3 q)$ \\
\hline Murrabrine Forest Road, Yowrie, NSW & $36^{\circ} 20^{\prime} 42.576^{\prime \prime S}, 149^{\circ} 45^{\prime} 33.12^{\prime \prime} \mathrm{E}$ & $20^{\star}$ & $9(1 \mathrm{~N}, 10,7$ ᄋ) \\
\hline Bridge over Colombo Creek, Bemboka, NSW & $36^{\circ} 38^{\prime} 8.9052^{\prime \prime} \mathrm{S}, 149^{\circ} 34^{\prime} 38.1792^{\prime \prime} \mathrm{E}$ & 19 & $2 q$ \\
\hline Rilys Road, Coolagolite, NSW & $36^{\circ} 22^{\prime} 58.6416^{\prime \prime} \mathrm{S}, 150^{\circ} 0^{\prime} 53.91^{\prime \prime} \mathrm{E}$ & $2(10,1$ \&) & 4 운 \\
\hline Wolgan Valley, NSW & $33^{\circ} 13^{\prime} 42.978^{\prime \prime} \mathrm{S}, 150^{\circ} 11^{\prime} 10.2948^{\prime \prime} \mathrm{E}$ & $2 U$ & $6(1 \mathrm{~L}, 5 \mathrm{~N})$ \\
\hline Wagga Wagga, NSW & $35^{\circ} 6^{\prime} 54.6696^{\prime \prime} \mathrm{S}, 147^{\circ} 22^{\prime} 32.5344^{\prime \prime} \mathrm{E}$ & 10 & 10 \\
\hline The Rock, NSW & $35^{\circ} 16^{\prime} 5.1528^{\prime \prime} S, 147^{\circ} 6^{\prime} 43.668^{\prime \prime} \mathrm{E}$ & $1 \mathrm{U}$ & 10 \\
\hline Werombi Road, Orangeville, NSW & $34^{\circ} 1^{\prime} 23.8728^{\prime \prime} \mathrm{S}, 150^{\circ} 39^{\prime} 22.7088^{\prime \prime} \mathrm{E}$ & $1 \mathrm{U}$ & 6 (4 N, 2 9) \\
\hline West Parade, Thirlmere, NSW & $34^{\circ} 13^{\prime} 16.9932^{\prime \prime} \mathrm{S}, 150^{\circ} 33^{\prime} 26.55^{\prime \prime} \mathrm{E}$ & $1 \mathrm{U}$ & $10(4 \mathrm{~N}, 30,3$ 9 $)$ \\
\hline West Parade, Couridjah, NSW & $34^{\circ} 13^{\prime} 38.6472^{\prime \prime S}, 150^{\circ} 33^{\prime} 11.124^{\prime \prime} \mathrm{E}$ & $1 \mathrm{U}$ & $9(7 \mathrm{~N}, 2$ P) \\
\hline Picton, NSW & $34^{\circ} 10^{\prime} 9.2856^{\prime \prime} \mathrm{S}, 150^{\circ} 36^{\prime} 32.5008^{\prime \prime} \mathrm{E}$ & $1 \mathrm{U}$ & $41(28 \mathrm{~N}, 7$ ठ, 6 9) \\
\hline Spring Creek Road, Mount Hunter, NSW & $34^{\circ} 4^{\prime} 53.976^{\prime \prime} \mathrm{S}, 150^{\circ} 37^{\prime} 46.2108^{\prime \prime} \mathrm{E}$ & 10 & $5(40,1$ o $)$ \\
\hline Eastview Drive, Orangeville NSW & $34^{\circ} 0^{\prime} 54.0756^{\prime \prime} \mathrm{S}, 150^{\circ} 35^{\prime} 11.9508^{\prime \prime} \mathrm{E}$ & $1 \sigma^{+}(J)$ & $16(6$ ơ, 10 q) \\
\hline Silverdale Road, The Oaks, NSW & $34^{\circ} 4^{\prime} 8.1624^{\prime \prime} \mathrm{S}, 150^{\circ} 34^{\prime} 25.6656^{\prime \prime} \mathrm{E}$ & 1 운 & $10(50,5$ o $)$ \\
\hline Moulders Road, Orangeville, NSW & $34^{\circ} 2^{\prime} 44.4804^{\prime \prime} \mathrm{S}, 150^{\circ} 34^{\prime} 23.4732^{\prime \prime} \mathrm{E}$ & 19 & 119 \\
\hline Couridjah, NSW & $34^{\circ} 13^{\prime} 54.8832^{\prime \prime} \mathrm{S}, 150^{\circ} 32^{\prime} 58.0308^{\prime \prime} \mathrm{E}$ & $1 \%$ & $9(20,7$ o $)$ \\
\hline Pheasants Nest Road, Pheasant Nest, NSW & $34^{\circ} 15^{\prime} 15.318^{\prime \prime} \mathrm{S}, 150^{\circ} 37^{\prime} 47.9784^{\prime \prime} \mathrm{E}$ & $10(P)$ & $2 \mathrm{~N}$ \\
\hline Mowbray Park Road, Mowbray Park, NSW & $34^{\circ} 9^{\prime} 39.51^{\prime \prime} \mathrm{S}, 150^{\circ} 32^{\prime} 54.1428^{\prime \prime} \mathrm{E}$ & 10 & $4(10,3$ o $)$ \\
\hline Buxton Road, Buxton, NSW & $34^{\circ} 15^{\prime} 4.5108^{\prime \prime} \mathrm{S}, 150^{\circ} 31^{\prime} 34.1688^{\prime \prime} \mathrm{E}$ & 19 & $26(2 \mathrm{~N}, 210,3$ o $)$ \\
\hline Kangaroo Valley, NSW & $34^{\circ} 44^{\prime} 31.7436^{\prime \prime} \mathrm{S}, 150^{\circ} 33^{\prime} 8.028^{\prime \prime} \mathrm{E}$ & $1 \cup(J)$ & $73(32 \mathrm{~N}, 15$ o, 26 ?) \\
\hline Bellmount Forest, NSW & $34^{\circ} 54^{\prime} 14.4612^{\prime \prime} \mathrm{S}, 149^{\circ} 14^{\prime} 54.0888^{\prime \prime} \mathrm{E}$ & 19 & $4(10,3 \mathrm{~N})$ \\
\hline Bellmount Forest, NSW & $34^{\circ} 53^{\prime} 58.7832^{\prime \prime S}, 149^{\circ} 14^{\prime} 53.2392^{\prime \prime} \mathrm{E}$ & 10 & $20(3 \mathrm{~N}, 15 \overbrace{}^{\star}, 2$ \&) \\
\hline Holbrook Road, Gelston Park, NSW & $34^{\circ} 13^{\prime} 33.9996^{\prime \prime} \mathrm{S}, 147^{\circ} 20^{\prime} 14.3088^{\prime \prime} \mathrm{E}$ & 10 & $370^{+}$ \\
\hline Rilys Road, Coolagolite, NSW & $36^{\circ} 22^{\prime} 58.7244^{\prime \prime} \mathrm{S}, 150^{\circ} 0^{\prime} 54.162^{\prime \prime} \mathrm{E}$ & 20 & $13(3 \mathrm{~N}, 100,9$ ᄋ $)$ \\
\hline Captains Flat Road, Primrose Valley, NSW & $35^{\circ} 27^{\prime} 14.8644^{\prime \prime} \mathrm{S}, 149^{\circ} 25^{\prime} 8.0544^{\prime \prime} \mathrm{E}$ & 10 & $3(10,2$ o $)$ \\
\hline Hard Road, Burra, NSW & $35^{\circ} 33^{\prime} 28.4436^{\prime \prime} \mathrm{S}, 149^{\circ} 13^{\prime} 19.3296^{\prime \prime} \mathrm{E}$ & $1 \%(J)$ & $44(38 \mathrm{~L}, 5 \mathrm{~N}, 1$ ð) \\
\hline Ironmungie Road, Dalgety NSW & $36^{\circ} 33^{\prime} 53.6148^{\prime \prime} \mathrm{S}, 148^{\circ} 55^{\prime} 7.5288^{\prime \prime} \mathrm{E}$ & $10^{+}$ & 79 \\
\hline Gidleigh Lane, Bungendore, NSW & $35^{\circ} 17^{\prime} 43.656^{\prime \prime} \mathrm{S}, 149^{\circ} 27^{\prime} 21.3192^{\prime \prime} \mathrm{E}$ & 1 ㅇ (J) & $14 \mathrm{~N}$ \\
\hline U & $U$ & $1 U$ & $10(2 \mathrm{~N}, 8$ \%) \\
\hline Cradle Mountain Road, Cradle Mountain, Tasmania & $41^{\circ} 31^{\prime} 23.2716^{\prime \prime} \mathrm{S}, 146^{\circ} 4^{\prime} 32.6388^{\prime \prime} \mathrm{E}$ & 1 ㅇ $(J)$ & $3(1 \mathrm{~N}, 2$ 9) \\
\hline
\end{tabular}

NSW New South Wales, GPS Global Positioning System, $U$ unknown, L larvae, N nymph, $P$ pinky (unfurred joey), J joey

Table 2 List of the tick species collected and identified from bare-nosed wombat ( $V$. ursinus) hosts between January 2019 and January 2020

\begin{tabular}{|c|c|c|c|c|}
\hline Tick species & Common name & No. collected & Instar & Locality \\
\hline Bothriocroton auruginans & Wombat tick & 420 & $\begin{array}{l}128 \text { o, } 141 \\
\text { o, } 112 \mathrm{~N} \\
39 \mathrm{~L}\end{array}$ & $\begin{array}{l}\text { NSW: Coolagolite, Rock Flat, Yowrie, Bellmount Forest, Bilpin, Bem- } \\
\text { boka, Buxton, Primrose Valley, Courijah, Orangeville, Bungendore, } \\
\text { Burra, Gelstone Park, Dalgety, Kangaroo Valley, Mowbray Park, } \\
\text { Pheasant Nest, Picton, Quaama, The Oaks, Mount Hunter, The } \\
\text { Rock, Wagga Wagga, Thirlmere, Wolgan Valley }\end{array}$ \\
\hline Haemaphysalis bancrofti & Wallaby tick & 8 & 8 오, $2 \mathrm{~N}$ & NSW: Coolagolite, Dalgety, Picton, Quaama \\
\hline Haemaphysalis longicornis & Bush tick & 3 & 10,2 우 & NSW: Coolagolite \\
\hline Ixodes tasmani & Common marsupial tick & 12 & $11 \mathrm{o}, 1 \mathrm{~N}$ & NSW: Dalgety. Tasmania: Cradle Mountain \\
\hline Ixodes holocyclus & Australian paralysis tick & 4 & 4 우 & NSW: Coolagolite, Quaama \\
\hline
\end{tabular}




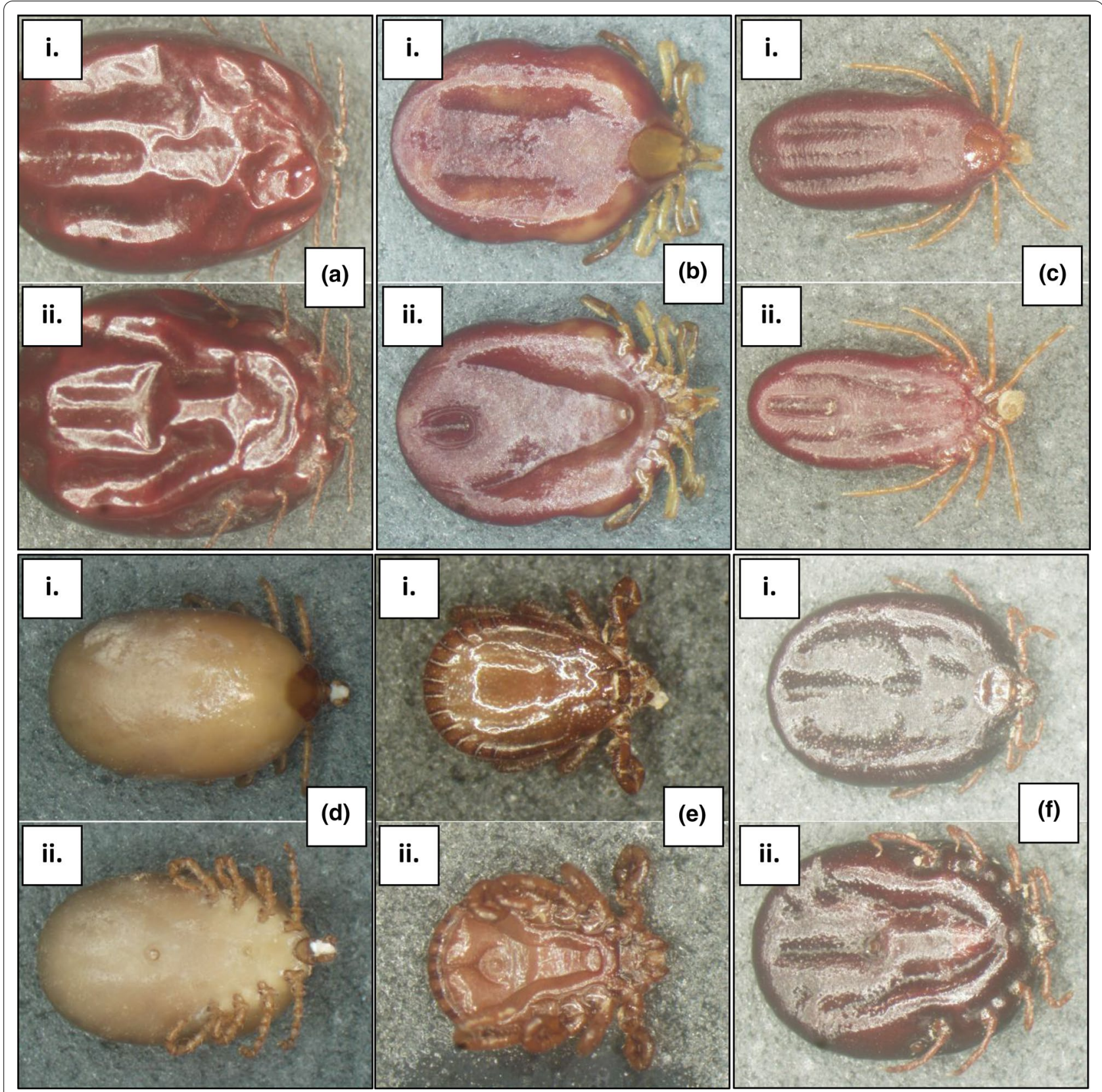

Fig. 2 a Bush tick Haemaphysalis longicornis female (i) dorsal, (ii) ventral; b Australian paralysis tick Ixodes holocyclus female (i) dorsal, (ii) ventral; c common marsupial tick Ixodes tasmani female (i) dorsal, (ii) ventral; $\mathbf{d}$ wombat tick Bothriocroton auruginans female (i) dorsal, (ii) ventral; e bush tick Haemaphysalis longicornis male (i) dorsal, (ii) ventral; f wallaby tick Haemaphysalis bancrofti female (i) dorsal, (ii) ventral

and often exhibited equal frequencies of three phyla. Male and female adult ticks were predominantly associated with Proteobacteria (Table 4).

Four OTUs (OTU_1, LC464975, 99\% identity; OTU_977, LC464975, 94.41\% identity; OTU_1383, LC464975, 98.51\% identity; and OTU_1806, CP014561, 93.26\% identity) were identified as a species of Coxiella closest matched to Coxiella burnetii and were detected in $72 \%$ of B. auruginans ( $86 \%$ of females, $68 \%$ of males, $39 \%$ of nymphs and $100 \%$ of larvae) but not detected in $I$. tasmani. Females had a mean prevalence of $51.7 \%$, males $30.7 \%$, nymphs $19.6 \%$ and larvae $82.3 \%$ for C. burnetii. The distribution of $C$. burnetii-infected ticks detected in this study is shown in Fig. 5.

OTU_9 was assigned to a Rickettsiella endosymbiont of the common marsupial tick (KP994859, 100\% identity) 


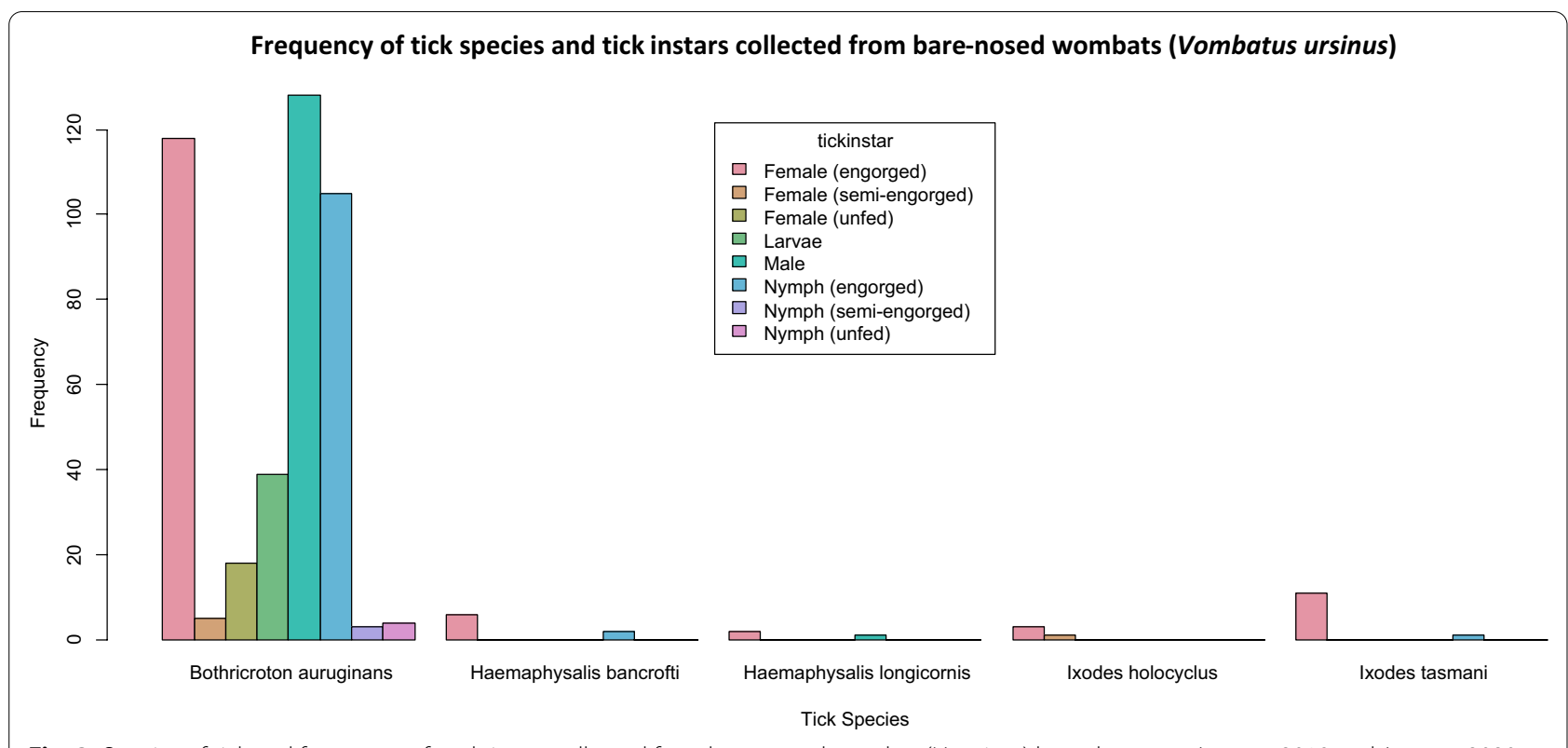

Fig. 3 Species of tick and frequency of each instar collected from bare-nosed wombat ( $V$. ursinus) hosts between January 2019 and January 2020

and comprised $94.5 \%$ of the bacterial diversity in the single female I. tasmani sample. This tick was collected from a wombat in Dalgety NSW, which is $100 \mathrm{~km}$ from the collection location of the wombat in Coolangubra NSW from which this sequence was originally isolated [6]. OTU_79 was assigned to Candidatus Borrelia ivorensis (KT364340, 99.53\% identity) and was detected in only one engorged adult female B. auruginans (2051 sequences) from Mowbray Park in NSW. An uncultured Anaplasma sp. (OTU_29, MK041546, 98.51\% identity) was detected in four female B. auruginans from Quaama, Coolagolite and The Oaks NSW.

The genus Staphylococcus was identified in six OTUs and was present in 66\% of samples. OTU_14 (MT214233, $100 \%$ identity) was assigned to Staphylococcus sciuri and was present in $21 \%$ of B. auruginans samples (29\% of females, $27 \%$ of males, no nymph or larvae) but not in I. tasmani. OTU_2 (MN314593, 100\% identity), OTU_1817 (MN314593, 96.50\% identity) and OTU_1923 (MN314593, 94.87\% identity) had a top BLAST hit of Staphylococcus agnetis and were present in 56\% of samples ( $60 \%$ of females, $41 \%$ of males, $56 \%$ of nymphs and $75 \%$ of larvae) including the common marsupial tick. Two additional OTUs were assigned to miscellaneous Staphylococcus spp. (OTU_15, MH549514, 100\% identity; and OTU_1791, MG572712, 99.53\% identity) but were represented in very low numbers of sequences.

Eight OTUs were assigned to the genus Streptococcus; however, only three were present in more than 100 sequences in any of the ticks. Streptococcus dysgalactiae (OTU_5, CP044102, 100\% identity) was detected in very high sequence numbers in four female $B$. auruginans collected in Orangeville NSW. Nine $B$. auruginans (two females, three males, three nymphs and one larvae) had Streptococcus salivarius (OTU_51, MN559932 100\% identity), and Streptococcus didelphis (OTU_1504, NR_115730, 99.53\% identity) was detected in a low number of sequences $(<200)$ in one female and one nymph of B. auruginans.

Escherichia coli (OTU_4, NZ_CP045277, 100\% identity) was identified in $21 \%$ of B. auruginans ticks ( $14 \%$ of females, $50 \%$ of nymphs, $50 \%$ of larvae and no males) but not in I. tasmani. OTUs that had a taxonomic identity associated with environmental bacteria such as Acidobacteria, Bacteroidetes and Cyanobacteria comprised $<4 \%$ of the total composition. Skin and soil-associated bacteria that occurred in high sequence numbers included Corynebacterium ulcerans (OTU_20, 100\% identity), Corynebacterium amycolatum (OTU_6, MK465377, 100\% identity), Macrococcus brunensis (OTU_8, MK097326, 100\% identity), Comamonas serinivorans (OTU_11, 9 CP021455, 9.77\% identity), Paraburkholderia caffeinilytica (OTU_17, MN150516, 100\% identity), and Dietzia timorensis (OTU_43, MN511783 $100 \%$ identity).

\section{Discussion}

This study aimed to record the species of ticks that feed on bare-nosed wombats and identify the bacteria associated with them. Five tick species were collected and included the first record of $H$. longicornis on bare-nosed wombats. A very high number of bacterial sequences 
Table 3 Bacterial composition of ticks parasitising bare-nosed wombat (V. ursinus) hosts between January 2019 and January 2020

\begin{tabular}{|c|c|c|c|c|c|}
\hline Tick species & Locality & Closest match in GenBank (\% similarity) & No. positive & Length (bp) & Bit-score \\
\hline \multirow[t]{13}{*}{ B. auruginans (wombat tick) } & \multirow[t]{13}{*}{ NSW } & Coxiella burnetii (99.07\%) & $56 / 78$ & 429 & 771 \\
\hline & & Staphylococcus sciuri (100\%) & $16 / 78$ & 429 & 793 \\
\hline & & Corynebacterium amycolatum (100\%) & $9 / 78$ & 410 & 758 \\
\hline & & Dermacoccus nishinomiyaensis (97.80\%) & $12 / 78$ & 409 & 706 \\
\hline & & Macrococcus brunensis (100\%) & $20 / 78$ & 429 & 793 \\
\hline & & Planomicrobium glaciei (100\%) & $4 / 78$ & 428 & 791 \\
\hline & & Lysinibacillus sp. (100\%) & $8 / 78$ & 426 & 787 \\
\hline & & Brachybacterium paraconglomeratum (100\%) & $13 / 78$ & 409 & 756 \\
\hline & & Escherichia coli (100\%) & $16 / 78$ & 429 & 793 \\
\hline & & Acinetobacter sp. (100\%) & 19/78 & 430 & 795 \\
\hline & & Pseudomonas sp. (100\%) & $7 / 78$ & 429 & 793 \\
\hline & & Candidatus Borrelia ivorensis (99.53) & $1 / 78$ & 424 & 784 \\
\hline & & Uncultured Anaplasma sp. (98.51\%) & $4 / 78$ & 404 & 713 \\
\hline I. tasmani (common marsupial tick) & NSW & Rickettsiella endosymbiont (100\%) & $1 / 1$ & 429 & 793 \\
\hline
\end{tabular}

Only taxa of interest are shown, and numbers of positive samples are based on samples with > 100 assigned operational taxonomic units (OTUs)

bp Base pair

were detected in wombat ticks, highlighting the effectiveness of NGS and the diversity of microorganisms in Australian ticks. Proteobacteria, Firmicutes and Actinobacteria dominated the bacterial profile, and the bacterial composition of the ticks studied supports similar investigations into these species [14, 17, 29].

The wombat tick $B$. auruginans is consistently the most prevalent tick found on bare-nosed wombats [46-48], and all instars except larvae were represented in this study. All larval specimens collected were identified as Bothriocroton sp. and shared their host with only $B$. auruginans instars. It is likely that these larval specimens were $B$. auruginans due to host specificity of other Bothriocroton spp.; however, this could not be confirmed. Heavy tick infestation has been associated with anaemia and poorer health parameters in other native marsupials $[49,50]$, and at least two of the wombats in this study were diagnosed with anaemia as a result of their tick burden (D. Kerr, personal communication). While it has been suggested that $B$. auruginans occurs throughout most of the bare-nosed wombat range in NSW [51], the only confirmed localities in the state are Burrawang [46], Tooloom, Armidale [30] and Wee Jasper [17]. This study provides additional locality reports for $B$. auruginans and highlights the abundance of this species on bare-nosed wombats. Despite the host specificity of $B$. auruginans, it has been suggested that it is likely a three-host tick like other Bothriocroton sp., which parasitize reptiles [30]; however, further research on the life cycle and seasonality of this species is needed.

Known as the bush tick in Australia and the cattle tick or Asian longhorned tick elsewhere, H. longicornis is an introduced three-host tick distributed from southeast Queensland to Victoria [52]. A new tick record for bare-nosed wombats, the bush tick collected in this study was positively differentiated from similar species by $5+5$ dentition and sharply pointed spurs on coxa 1 [30]. The adult male bush tick found in Coolagolite NSW is particularly unusual considering this species is an obligate parthenogen in Australia, resulting in males being quite rare [53]. Cattle, sheep and horses are the preferred hosts for this species, but it has also been collected from humans, domestic animals, various species of birds, black-striped wallabies (Wallabia dorsalis), northern brown bandicoots (Isoodon macrourus) and common wallaroos (Macropus robustus) [30, 31]. The three specimens collected in this study were from a free-ranging wombat on a 100-acre property with no active livestock; however, access to properties with livestock is possible across dried creek beds at certain times of the year (D. Ondinea, personal communication). The bush tick has been extensively studied overseas and is considered a vector of bacteria, viruses and protozoa, in particular C. burnetii [54], Ehrlichia chaffeensis, Borrelia spp. [55], and Theileria orientalis [56]; however, transmission has not been shown to occur in Australian specimens [57].

The Australian paralysis tick is well known for causing tick paralysis in domestic animals and humans [58]. Native Australian marsupials and eutherians have, however, co-evolved with the Australian paralysis tick, are the natural hosts for this tick and are typically immune to tick paralysis [59]. Found along the entire east coast of Australia, the Australian paralysis tick is an eclectic 


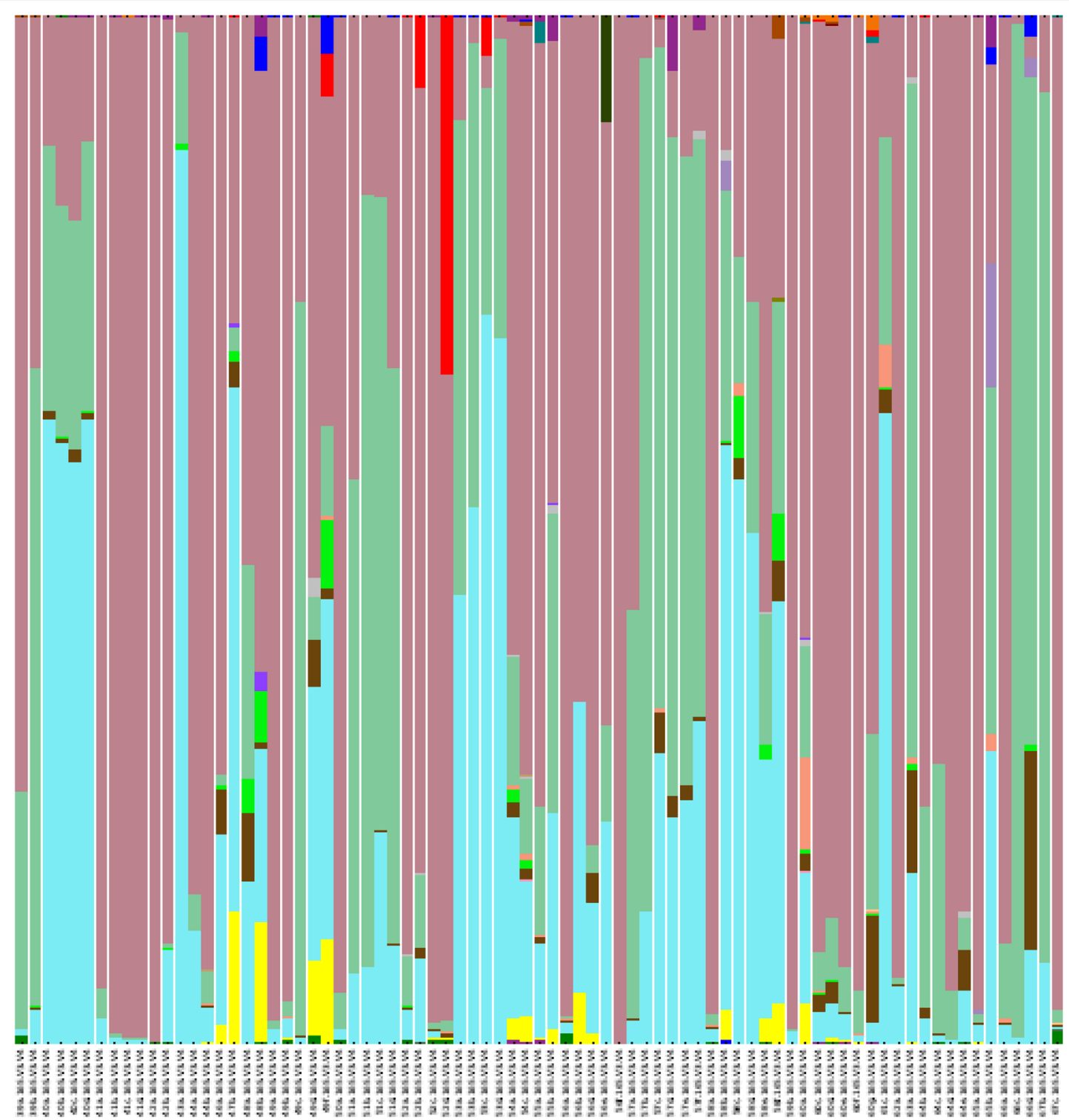

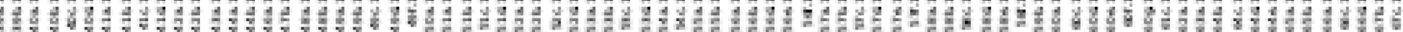

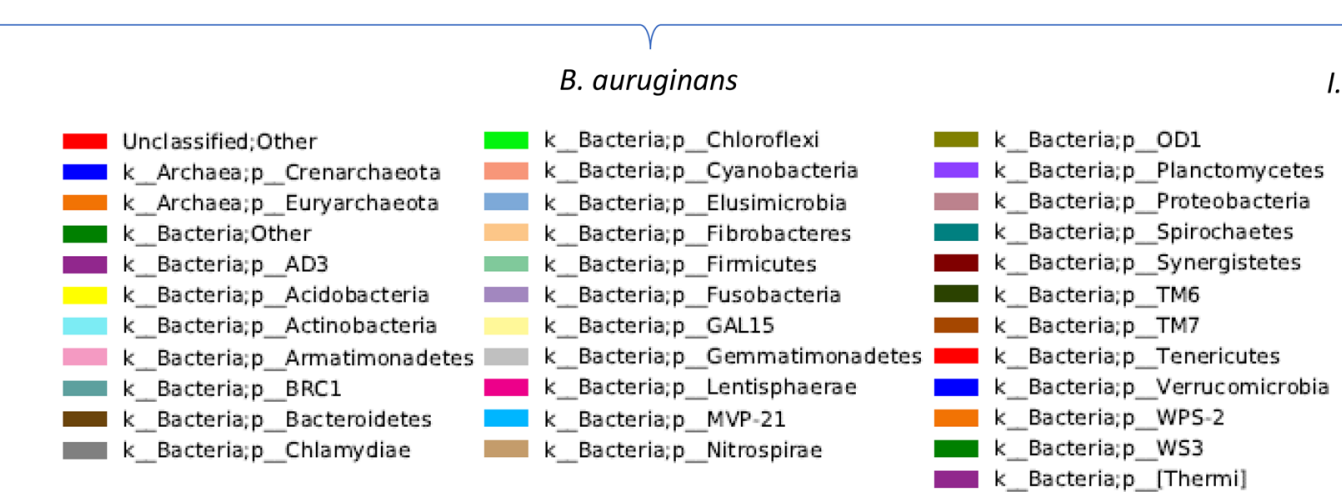

Fig. 4 Taxonomic summary of bacterial phyla found in wombat ticks between January 2019 and January 2020 
Table 4 List of wombat tick samples sequenced on the Illumina MiSeq platform and absolute OTU counts for each sample

\begin{tabular}{|c|c|c|c|c|c|c|c|}
\hline Sample code & Species & Common name & Sex & Instar & $\begin{array}{l}\text { Total abundance } \\
\text { C. burnetii }\end{array}$ & $\begin{array}{l}\text { Total abundance } \\
\text { Staphylococcus agnetis }\end{array}$ & $\begin{array}{l}\text { Total } \\
\text { abundance } \\
\text { Rickettsiella }\end{array}$ \\
\hline $39 a$ & B. auruginans & Wombat tick & Female & Adult & 96,850 & 240 & 0 \\
\hline $39 b$ & B. auruginans & Wombat tick & Female & Adult & 38,832 & 617 & 0 \\
\hline $40 a$ & B. auruginans & Wombat tick & Male & Adult & 424 & 86 & 0 \\
\hline $40 b$ & B. auruginans & Wombat tick & Male & Adult & 499 & 37 & 0 \\
\hline $40 c$ & B. auruginans & Wombat tick & Male & Adult & 0 & 52 & 0 \\
\hline $40 d$ & B. auruginans & Wombat tick & Male & Adult & 245 & 33 & 0 \\
\hline $41 a$ & B. auruginans & Wombat tick & Female & Adult & 118,871 & 23 & 0 \\
\hline $41 b$ & B. auruginans & Wombat tick & Female & Adult & 135,810 & 1 & 0 \\
\hline $41 c$ & B. auruginans & Wombat tick & Female & Adult & 151,567 & 0 & 0 \\
\hline $41 d$ & B. auruginans & Wombat tick & Female & Adult & 35,440 & 0 & 0 \\
\hline $42 \mathrm{a}$ & B. auruginans & Wombat tick & Female & Adult & 121,194 & 0 & 0 \\
\hline $42 b$ & B. auruginans & Wombat tick & Male & Adult & 11,701 & 0 & 0 \\
\hline $43 a$ & B. auruginans & Wombat tick & Female & Adult & 42 & 49 & 0 \\
\hline $44 a$ & B. auruginans & Wombat tick & Female & Adult & 22,187 & 3 & 0 \\
\hline $44 b$ & B. auruginans & Wombat tick & Female & Adult & 150,092 & 74 & 0 \\
\hline $46 a$ & B. auruginans & Wombat tick & Female & Adult & 8363 & 0 & 0 \\
\hline $47 b$ & B. auruginans & Wombat tick & Female & Adult & 0 & 0 & 0 \\
\hline $48 a$ & B. auruginans & Wombat tick & - & Nymph & 7320 & 0 & 0 \\
\hline $48 b$ & B. auruginans & Wombat tick & Female & Adult & 694 & 0 & 0 \\
\hline $49 a$ & B. auruginans & Wombat tick & - & Nymph & 56,494 & 0 & 0 \\
\hline $49 b$ & B. auruginans & Wombat tick & Male & Adult & 82,607 & 155 & 0 \\
\hline $49 c$ & B. auruginans & Wombat tick & Male & Adult & 28,893 & 51,956 & 0 \\
\hline $49 d$ & B. auruginans & Wombat tick & - & Nymph & 0 & 0 & 0 \\
\hline $49 f$ & B. auruginans & Wombat tick & Male & Adult & 0 & 1158 & 0 \\
\hline $50 a$ & B. auruginans & Wombat tick & Female & Adult & 87,091 & 160 & 0 \\
\hline $51 a$ & B. auruginans & Wombat tick & Female & Adult & 6965 & 328 & 54 \\
\hline $51 b$ & B. auruginans & Wombat tick & Female & Adult & 172 & 100 & 0 \\
\hline $51 c$ & B. auruginans & Wombat tick & Male & Adult & 0 & 194 & 0 \\
\hline $51 d$ & B. auruginans & Wombat tick & Male & Adult & 0 & 293 & 69 \\
\hline $52 a$ & B. auruginans & Wombat tick & Female & Adult & 47,707 & 1719 & 0 \\
\hline $52 b$ & B. auruginans & Wombat tick & Female & Adult & 36,035 & 1682 & 0 \\
\hline $52 \mathrm{c}$ & B. auruginans & Wombat tick & Male & Adult & 107,270 & 195 & 0 \\
\hline $52 d$ & B. auruginans & Wombat tick & Male & Adult & 47,213 & 432 & 0 \\
\hline $53 a$ & B. auruginans & Wombat tick & Female & Adult & 12,669 & 520 & 0 \\
\hline $53 b$ & B. auruginans & Wombat tick & Female & Adult & 3819 & 1029 & 0 \\
\hline $53 c$ & B. auruginans & Wombat tick & Female & Adult & 2535 & 1130 & 0 \\
\hline $53 d$ & B. auruginans & Wombat tick & Female & Adult & 2314 & 3475 & 0 \\
\hline $54 a$ & B. auruginans & Wombat tick & Female & Adult & 47 & 2612 & 0 \\
\hline $54 c$ & B. auruginans & Wombat tick & Female & Adult & 6442 & 137 & 0 \\
\hline $55 a$ & B. auruginans & Wombat tick & Female & Adult & 76,233 & 6706 & 0 \\
\hline $55 b$ & B. auruginans & Wombat tick & Male & Adult & 4771 & 119 & 0 \\
\hline $56 a$ & B. auruginans & Wombat tick & Male & Adult & 72,344 & 0 & 0 \\
\hline $56 b$ & B. auruginans & Wombat tick & Male & Adult & 0 & 0 & 0 \\
\hline $56 d$ & B. auruginans & Wombat tick & Male & Adult & 20,493 & 0 & 0 \\
\hline $56 e$ & B. auruginans & Wombat tick & Male & Adult & 2468 & 0 & 0 \\
\hline $56 f$ & B. auruginans & Wombat tick & Male & Adult & 0 & 0 & 0 \\
\hline $57 a$ & B. auruginans & Wombat tick & - & Nymph & 0 & 39,411 & 0 \\
\hline $57 b$ & B. auruginans & Wombat tick & - & Nymph & 2 & 106,880 & 0 \\
\hline
\end{tabular}


Table 4 (continued)

\begin{tabular}{|c|c|c|c|c|c|c|c|}
\hline Sample code & Species & Common name & Sex & Instar & $\begin{array}{l}\text { Total abundance } \\
\text { C. burnetii }\end{array}$ & $\begin{array}{l}\text { Total abundance } \\
\text { Staphylococcus agnetis }\end{array}$ & $\begin{array}{l}\text { Total } \\
\text { abundance } \\
\text { Rickettsiella }\end{array}$ \\
\hline $57 c$ & B. auruginans & Wombat tick & - & Nymph & 0 & 5956 & 0 \\
\hline $57 d$ & B. auruginans & Wombat tick & - & Nymph & 0 & 5700 & 0 \\
\hline $57 e$ & B. auruginans & Wombat tick & - & Nymph & 0 & 12,343 & 0 \\
\hline $57 f$ & B. auruginans & Wombat tick & - & Nymph & 0 & 9720 & 0 \\
\hline $58 a$ & B. auruginans & Wombat tick & Male & Adult & 107,406 & 44 & 0 \\
\hline $58 b$ & B. auruginans & Wombat tick & Male & Adult & 1859 & 348 & 0 \\
\hline $58 c$ & B. auruginans & Wombat tick & Male & Adult & 9 & 0 & 0 \\
\hline $58 d$ & B. auruginans & Wombat tick & - & Nymph & 449 & 0 & 0 \\
\hline $58 \mathrm{e}$ & B. auruginans & Wombat tick & - & Nymph & 9918 & 0 & 0 \\
\hline $58 f$ & B. auruginans & Wombat tick & - & Nymph & 8 & 0 & 0 \\
\hline $59 b$ & B. auruginans & Wombat tick & - & Nymph & 93,668 & 0 & 0 \\
\hline $60 a$ & B. auruginans & Wombat tick & Male & Adult & 8398 & 1543 & 0 \\
\hline $60 c$ & B. auruginans & Wombat tick & Male & Adult & 128,271 & 30 & 0 \\
\hline $60 d$ & B. auruginans & Wombat tick & Male & Adult & 92,622 & 99 & 0 \\
\hline $60 e$ & B. auruginans & Wombat tick & Male & Adult & 99,967 & 3503 & 0 \\
\hline $60 f$ & B. auruginans & Wombat tick & Male & Adult & 129,252 & 5470 & 0 \\
\hline $60 \mathrm{~g}$ & B. auruginans & Wombat tick & Male & Adult & 55,074 & 903 & 0 \\
\hline $61 c$ & B. auruginans & Wombat tick & - & Nymph & 1709 & 1 & 0 \\
\hline $62 \mathrm{a}$ & B. auruginans & Wombat tick & Female & Adult & 131,882 & 1 & 0 \\
\hline $63 a$ & B. auruginans & Wombat tick & Male & Adult & 101 & 3536 & 0 \\
\hline $64 b$ & B. auruginans & Wombat tick & - & Larvae & 37,394 & 1684 & 0 \\
\hline $64 c$ & B. auruginans & Wombat tick & - & Larvae & 61,504 & 14,953 & 0 \\
\hline $64 d$ & B. auruginans & Wombat tick & - & Larvae & 61,897 & 466 & 0 \\
\hline $64 \mathrm{e}$ & B. auruginans & Wombat tick & - & Larvae & 27,290 & 0 & 0 \\
\hline $65 a$ & B. auruginans & Wombat tick & Female & Adult & 147,715 & 143 & 14 \\
\hline $65 b$ & B. auruginans & Wombat tick & Female & Adult & 0 & 1453 & 1 \\
\hline $66 a$ & B. auruginans & Wombat tick & - & Nymph & 118,704 & 969 & 0 \\
\hline $66 c$ & B. auruginans & Wombat tick & - & Nymph & 0 & 17,181 & 0 \\
\hline $66 d$ & B. auruginans & Wombat tick & - & Nymph & 0 & 3741 & 0 \\
\hline $67 b$ & B. auruginans & Wombat tick & - & Nymph & 0 & 6881 & 0 \\
\hline $67 c$ & Ixodes tasmani & Common marsupial tick & Female & Adult & 0 & 173 & 85,653 \\
\hline
\end{tabular}

feeder and has been found on many different bird and mammal species; however, in certain areas it is dependent upon bandicoots to survive between seasons [30]. All specimens collected in this study were engorged females; however, adult males are rarely seen, as mating occurs off the host and adult male ticks feed on adult female ticks as opposed to the mammalian hosts [60]. With the use of targeted blocking primers a relapsing fever Borrelia sp. was recently isolated from a single Australian paralysis tick collected from an echidna [13], highlighting the hidden pathogenic potential of this species.

Like the Australian paralysis tick, the common marsupial tick is similarly indiscriminate in its feeding habits having been found on various wildlife, domestic animals and humans. However, it is the most widespread Ixodes species in Australia and has been associated with various pathogens such as Rickettsia, Rickettsiella, Bartonella, Theileria, nematodes and Hepatozoon [29, 61-66]. Regularly found on bare-nosed wombats in low numbers [48, 67], I. tasmani is a nidicolous species that detaches from its nocturnal vertebrate hosts during the day and is therefore likely associated with wombat burrows. Given its fast reproductive rate, three-host life cycle and the variety of pathogenic organisms that it typically harbours, this species is likely to pose a disease threat to wombats and wombat handlers; however, more research needs to be conducted to determine the extent of this threat.

An endemic tick that primarily feeds on macropods, wallaby tick is predominantly distributed throughout coastal Queensland and northern NSW, and apart 


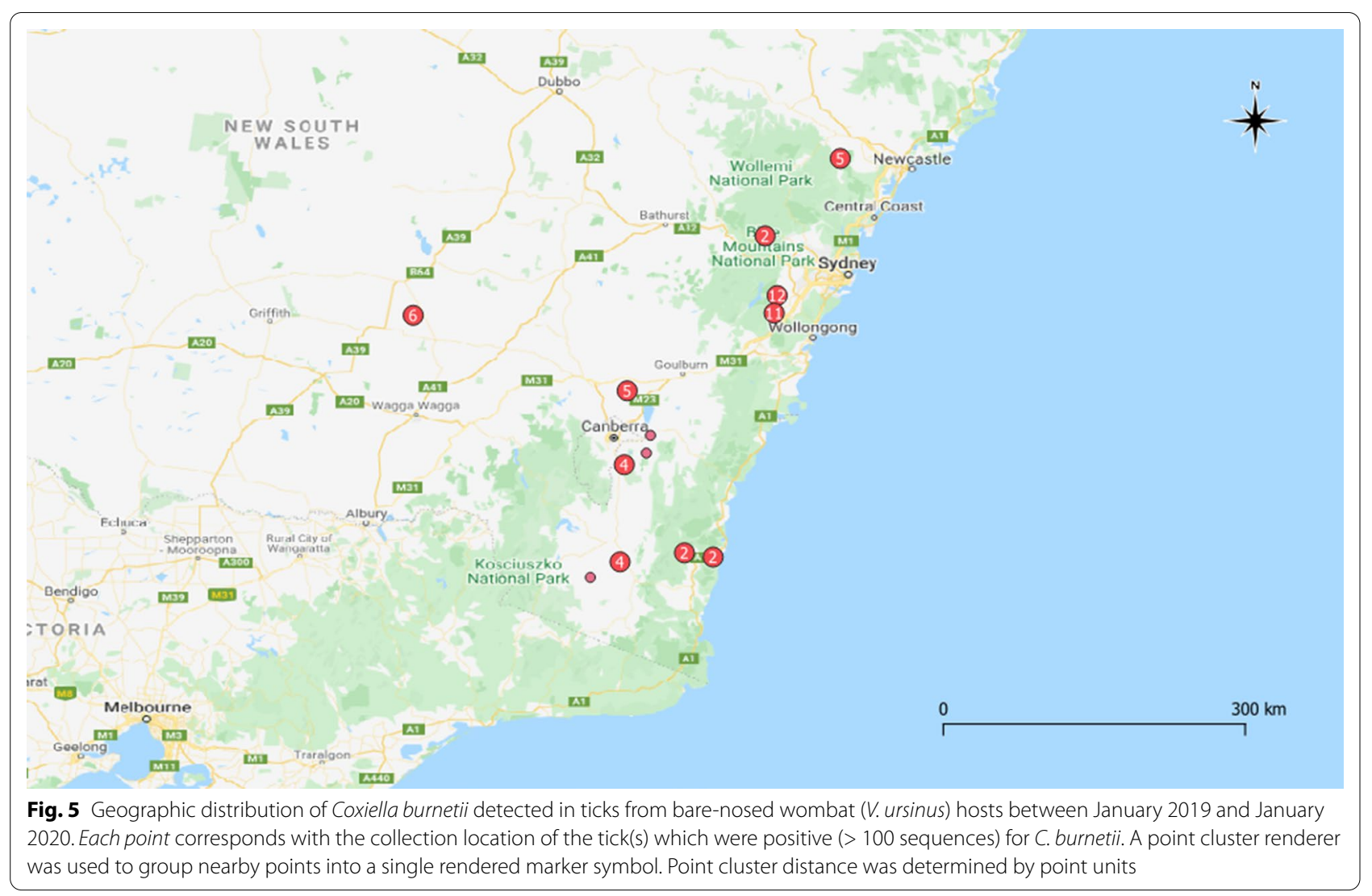

from a disjunct population on Raymond Island Victoria, the southernmost reports of this species are from a bare-nosed wombat, a red-necked wallaby (Macropus rufogriseus) and a swamp wallaby (Wallabia bicolor) in the Nadgee State Forest NSW [24]. The specimens collected in the present study were from Dalgety and Quaama NSW, which are located approximately $2 \mathrm{~h}$ north of Nadgee. These new specimens further confirm the presence of wallaby tick in the far south NSW region and provide the second account of this species feeding on bare-nosed wombats [24]. Although macropods are the native host for $H$. bancrofti, there are more records of this species from cattle than native animals [24], and it is one of the main vectors of T. orientalis that impacts cattle in Australia [57, 68].

Analysis of alpha-diversity (Fig. 6) showed high variability across both sample locations and instars, similar to previous studies $[17,69]$. However, there was some similarity between the same instars from the same collection location. Diversity can vary greatly between tick studies depending on extraction methods, the quality of filtering and bioinformatic analysis. All samples in this study underwent identical extraction, library preparation and bioinformatic analysis so it is possible that this affected sequencing depth of samples. It has been noted that for some species of native ticks, including the wombat tick, a larger number of sequences is required to produce an accurate representation of bacterial diversity [17]. The most abundant and diverse phylum was the Proteobacteria, which is consistent with similar studies of native hard ticks $[29,70]$.

Pathogens previously isolated from B. auruginans include C. burnetii, Rickettsia massiliae and Rickettsia typhi [29] and varying levels of Proteobacteria and Firmicutes $[14,17]$. The very high prevalence of $C$. burnetii found in all $B$. auruginans instars in this study is similar to previous findings in this species [29]. Coxiella-like organisms are known to be highly efficient at transovarial transmission between tick hosts [71], and their presence within Malpighian tubules may suggest that they play a role in tick nutrition [7]. Different strains of $C$. burnetii have been shown to be highly related (>99\%) based on 16S rRNA, highlighting that the species recently evolved from an ancestral symbiont of ticks [6]. Because B. auruginans exhibits such remarkable host specificity, it is unlikely that this species is a significant vector for C. burnetii in humans. It is unknown, however, what impact this pathogen has on both healthy and sarcoptic mange-affected wombats. Blood and urine samples taken from wombats 
have failed to indicate the presence of C. burnetii [72], whereas other native marsupials such as the koala, bandicoots and macropods are regularly found to be seropositive for this bacterium [73-75]. Further studies to investigate the presence of $C$. burnetii in wombat faeces and blood, and in parasites other than $B$. auruginans, may be beneficial to determine the importance, role and impact of this pathogen in wombats and wombat ticks.

The presence of Borrelia in Australian ticks is a recent discovery [13], and targeted approaches using blocking primers and highly conserved housekeeping genes have provided insights into potential reservoirs and vectors of novel Borrelia sp. in Australia [14]. A species of Borrelia had the closest match to Candidatus Borrelia ivorensis and was detected in a single Bothriocroton auruginans from NSW. The original isolate for this species was from Amblyomma variegatum in western Africa, and it is more closely related to the relapsing fever Borrelia group than the Lyme group [76]. The uncultured Anaplasma sp. detected was originally isolated from an echidna tick (Bothriocroton concolor). All recognised Anaplasma spp. are obligate intracellular tick-borne mammalian pathogens [77], and as transovarial transmission between ticks has not yet been shown, it is believed that this genus persists solely through infected mammalian hosts [78].

A commensal bacterium of the mammalian gastrointestinal tract, E. coli is commonly found in native mammals, with the highest prevalence in herbivorous mammals with larger body masses [79]. Some species of E. coli are zoonotic and impact human health [80]. One study found northern hairy-nosed wombats (Lasiorhinus krefftii) to have an E. coli prevalence of $80 \%$ and southern hairy-nosed wombats (Lasiorhinus latifrons) to have $86 \%$ [79]; however, another study found no zoonotic E. coli in all three species of wombats [81]. While a strain of $E$. coli occurs in $B$. auruginans, it has been shown that ticks exhibit various innate immune responses to this bacterium $[82,83]$ and it is destroyed in the body of the tick rather than harboured and transmitted.

Ticks are often found to have large quantities of bacteria that are associated with the soil environments in which they spend most of their lives, in addition to bacteria associated with the skin of their mammalian hosts [13, 84]. Some pathogenic environmental and skin-associated bacteria that were detected in both the wombat tick and common marsupial tick may have potential implications for wombats with sarcoptic mange, or could even have been detected as a result of the ticks feeding on wombats with sarcoptic mange-associated bacteria.

Members of the genus Staphylococcus are typically commensals of mammalian skin, and are commonly found in ticks of native Australian wildlife [84, 85]; some species such as Staphylococcus aureus are associated with Sarcoptes scabiei mites and responsible for causing scabies-associated pyoderma in humans [86]. Two species of Staphylococcus were detected in this study: S. agnetis, which is typically associated with clinical disease in cattle and poultry [87, 88], and S. sciuri, which is a skin-associated bacterium acquired through contact with host skin [84]. Staphylococcus sciuri has also been detected in fleas from bandicoots and dogs in Australia, and in various lice and tick species including $I$. holocyclus and H. longicornis [85].

Further skin-related bacteria found included C. ulcerans, which causes a zoonotic infection similar to diphtheria [88], Dolosigranulum pigrum, which is associated with pneumonia in humans $[89,90]$, and Macrococcus brunensis, which is phylogenetically similar to a species of Macrococcus responsible for causing skin infection in dogs [91]. At least three distinct species of Streptococcus were detected, of which S. dysgalactiae and S. didelphis are important pathogens of humans and animals causing skin infection [92, 93]. Other species of Streptococcus such as Streptococcus pyogenes from Sarcoptes scabiei mites are responsible for causing skin infection in humans [86]. The pathogenicity and consequences of these skin-associated bacteria on both healthy and sarcoptic mangeimpacted wombats may therefore be important.

Endosymbiotic bacteria are an important component of the tick microbiome and often play a role in tick reproductive and nutritional fitness [15]. The tick endosymbionts found in this study include Rickettsiella, Acinetobacter and Pseudomonas. The genera Acinetobacter and Pseudomonas have previously been isolated from wombat fleas [85]; they are also found in all Ixodes examined, and are believed to play an important role in the physiological processes of ticks [93]. Despite I. tasmani exhibiting a very high prevalence of a Rickettsiella endosymbiont, some known tick endosymbionts such as $\mathrm{Wol}$ bachia and Francisella were not detected in this study.

It is believed that bacterial endosymbionts are dominant in the majority of ixodid ticks [9], and there are examples of endosymbiotic bacteria so abundant they mask other microbes including pathogens, for example Candidatus Midichloria mitochondrii in the Australian paralysis tick [13]. DNA extracted from whole tick specimens, in particular those which have fed from their vertebrate hosts, will contain tick DNA, host DNA and microbial DNA (i.e. bacterial, viral, eukaryotic). The presence of host DNA in engorged ticks has been known to cause difficulties due to inhibitory properties in mammalian blood [94], so a targeted approach is required when examining bacterial communities. Popular genetic markers used for molecular identification of ticks and their associated bacteria, include the cytochrome $c$ 


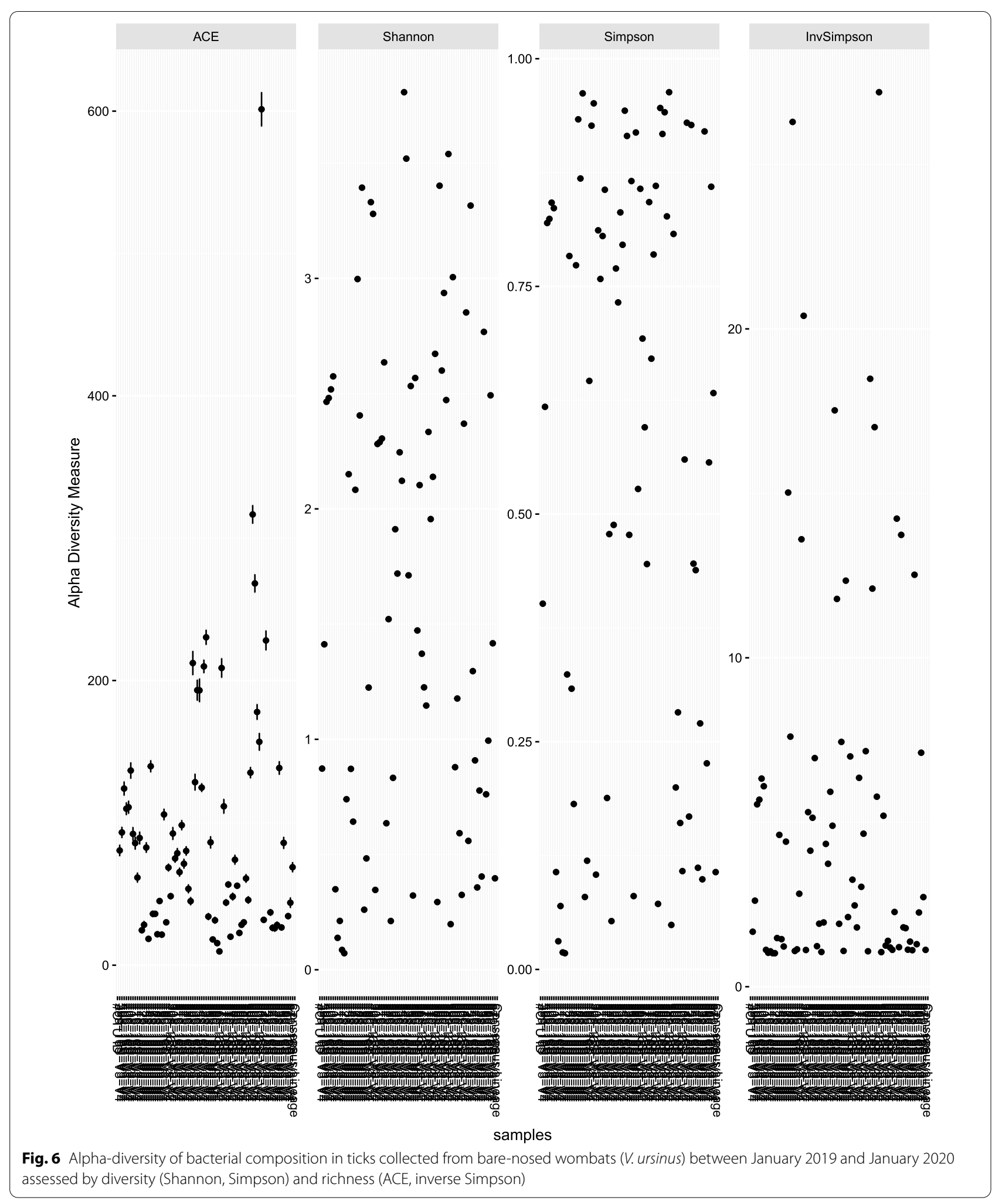


oxidase subunit 1 (COI) protein-coding gene, and the $16 \mathrm{~S}$ rRNA, 12S rRNA and 18S rRNA genes [94]. Each has its advantages and limitations, for example COI offers an extensive existing library of universal primers as it is the standard marker for barcoding of animal species; however, it is limited in its ability to distinguish certain groups of organisms such as the Ixodidae to species level. The 16S rRNA gene is the most commonly used molecular marker because it can accurately distinguish between most prokaryotic taxa, but some microbial groups such as Rickettsiales may be difficult to distinguish due to their interspecific 16S rRNA similarity [95]. There are nine hypervariable regions of bacterial 16S rRNA genes that can be effectively targeted to identify bacterial taxa (V1V9), and regions V1-V4 have been most commonly used in ticks [15].

The sampling method used in this study was both economical and allowed for a fair assessment of tick infestation rates on wombat hosts. However, it can be assumed that in some cases smaller nymphal and larval tick instars were likely overlooked. It is also likely that some ticks had left road-killed wombats which were opportunistically sampled, despite Skerratt et al. [48] finding no difference between tick density on live or road-killed wombats. The high abundance of female instars is likely indicative of some collection bias due to their larger size. The collection of ticks from animals in care limits the assessment of the origin of tick species and species of microorganisms due to the uncertainty of whether the ticks attached in the location of rehabilitation or the original habitat where the wombat was collected from. Three species of ticks collected from wombats (the wallaby, bush and Australian paralysis tick) could not be processed for bacterial presence in this study. However, these tick species are known vectors of significant pathogens of domestic animals and humans, and as a result have been extensively studied. All the ticks collected in this study except for the Australian paralysis tick were non-nidicolous hard ticks and presumably picked up by the wombat hosts whilst they were grazing. Many of the wombats used in this study were also in an atypical environment and had not had recent exposure to burrows. Considering that the majority of soft ticks are nidicolous and feed for very short periods of time, further investigation into the ticks associated with wombat burrows would provide a broader perspective of all the tick species associated with wombats.

\section{Conclusions}

This study builds upon recent wildlife tick research and provides the first focused investigation into the ticks and tick-associated bacteria of bare-nosed wombats. The detection of various Proteobacteria in this study highlights the high bacterial diversity in native Australian ticks that was unrecognised prior to the development of NGS. Furthermore, the detection of $C$. burnetii in a large proportion of wombat ticks highlights the need for further investigation into wombat ectoparasites and their associated pathogens, in addition to the ability of wombats to cope with these pathogens and tick burdens in the presence of sarcoptic mange. The complex and dynamic relationships between vertebrate wildlife hosts, ticks and pathogens are continuously highlighted in the northern hemisphere $[96,97]$. The unique evolutionary history of Australian fauna and tick species is shown in the distinct diversity yet taxonomic differences of these tick-hostpathogen relationships from those overseas. With the advancement of molecular methods the extent of these unique evolutionary relationships will become clearer, and may lead to potential improvements in the management of vector-borne diseases such as sarcoptic mange.

\section{Abbreviations}

NGS: Next-generation sequencing; OTU: Operational taxonomic unit; COI: Cytochrome $c$ oxidase subunit 1 .

\section{Acknowledgements}

Thank you to Amanda Cox, Danie Ondinea, Bronlow Hall, Inga Schwaiger, Belinda Goldsworthy, Lyn Oberon, Diane Hinton, Liesl Perryman, Elena Guarracino, Pru Carpenter and Deborah Kerr for assisting with tick collection, and Siobhon Egan for assisting with tick identification. Donations to Wombat Giving available through the WomSAT website funded this project.

\section{Authors' contributions}

HJS and JMO: Conceptualized the study and provided supervision and validation for the study. DB: Obtained the samples, analysed the data and wrote the original draft of the manuscript. All authors read and approved the final manuscript.

\section{Funding}

Western Sydney University, Wombat Giving.

\section{Availability of data and materials}

The datasets used and/or analysed during the current study are available from the corresponding author on reasonable request. Voucher specimens have been submitted to the Australian Museum and include Bothricroton auruginans KS.130891, Haemaphysalis bancrofti KS.130892, Ixodes holocyclus KS.130893, Ixodes holocyclus KS.130893, Haemaphysalis longicornis KS.130894 and Ixodes tasmani KS.130895.

\section{Ethics approval and consent to participate}

The collection of invertebrates described here did not require ethics approval.

\section{Consent for publication}

Not applicable.

\section{Competing interests}

The authors declare that they have no competing interests.

\section{Author details}

${ }^{1}$ School of Science, Western Sydney University, Penrith, New South Wales, Australia. ${ }^{2}$ School of Animal and Veterinary Sciences, Charles Sturt University, Wagga Wagga, NSW, Australia.

Received: 1 May 2020 Accepted: 28 December 2020

Published online: 19 January 2021 


\section{References}

1. Sonenshine DE, Roe RM. Biology of ticks. Oxford: Oxford University Press; 2013

2. Dantas-Torres F, Chomel BB, Otranto D. Ticks and tick-borne diseases: a One Health perspective. Trends Parasitol. 2012;28(10):437-46.

3. Randolph SE. The impact of tick ecology on pathogen transmission dynamics. Ticks. 2008;40:72.

4. Narasimhan S, Fikrig E. Tick microbiome: the force within. Trends Parasitol. 2015:31:315-23. https://doi.org/10.1016/j.pt.2015.03.010.

5. Bonnet SI, Binetruy F, Hernandez-Jarguin AM, Duron O. The tick microbiome: why non-pathogenic microorganisms matter in tick biology and pathogen transmission. Front Cell Infect Microbiol. 2017;7:236. https:// doi.org/10.3389/fcimb.2017.00236.

6. Duron O, Noel V, McCoy KD, Bonazzi M, Sidi-Boumedine K, Morel O, et al. The recent evolution of a maternally-inherited endosymbiont of ticks led to the emergence of the $\mathrm{Q}$ fever pathogen Coxiella burnetii. PLOS Pathog. 2015;11:e1004892. https://doi.org/10.1371/journal.ppat.1004892.

7. Smith TA, Driscoll T, Gillespie JJ, Raghavan R. A Coxiella-like endosymbiont is a potential vitamin source for the lone star tick. Genome Biol Evol. 2015;7(3):831-8. https://doi.org/10.1093/gbe/evv016.

8. Cowdry EV. A group of microorganisms transmitted hereditarily in ticks and apparently unassociated with disease. J Exp Med. 1925;41(6):817-30.

9. Noda H, Munderloh UG, Kurtti TJ. Endosymbionts of ticks and their relationship to Wolbachia spp. and tick-borne pathogens of humans and animals. Appl Environ Microbiol. 1997;63:3926-32.

10. Irwin P, Egan S, Greay T, Oskam C. Bacterial tick-associated infections in Australia: current studies and future directions. Microbiol Aust. 2018;12:35

11. Buettner PG, Westcott DA, Maclean J, Brown L, McKeown A, Johnson A, et al. Tick paralysis in spectacled flying-foxes (Pteropus conspicillatus) in North Queensland, Australia: impact of a ground-dwelling ectoparasite finding an arboreal host. PLoS ONE. 2013;8:e73078. https://doi. org/10.1371/journal.pone.0073078.

12. Gofton AW, Doggett $S$, Ratchford A, Oskam CL, Paparini A, Ryan U, et al. Bacterial profiling reveals novel "Ca. Neoehrlichia", Ehrlichia, and Anaplasma species in Australian human-biting ticks. PLOS ONE. 2015;10:e0145449. https://doi.org/10.1371/journal.pone.0145449.

13. Gofton AW, Oskam CL, Lo N, Beninati T, Wei H, McCarl V, et al. Inhibition of the endosymbiont "Candidatus Midichloria mitochondrii" during 165 rRNA gene profiling reveals potential pathogens in Ixodes ticks from Australia. Parasites Vectors. 2015;8:345. https://doi.org/10.1186/s13071-015-0958-3.

14. Loh SM, Gofton AW, Lo N, Gillett A, Ryan UM, Irwin PJ, et al. Novel Borrelia species detected in echidna ticks, Bothriocroton concolor, in Australia. Parasites Vectors. 2016;9:339. https://doi.org/10.1186/s13071-016-1627-x.

15. Greay TL, Gofton AW, Paparini A, Ryan UM, Oskam CL, Irwin PJ. Recent insights into the tick microbiome gained through next-generation sequencing. Parasites Vectors. 2018;11:12. https://doi.org/10.1186/s1307 1-017-2550-5.

16. Gofton AW, Waudby HP, Petit S, Greay TL, Ryan UM, Irwin PJ. Detection and phylogenetic characterisation of novel Anaplasma and Ehrlichia species in Amblyomma triguttatum subsp. from four allopatric populations in Australia. Ticks Tick-borne Dis. 2017;8:749-56. https://doi.org/10.1016/j. ttbdis.2017.05.009.

17. Egan SL, Loh SM, Banks PB, Gillett A, Ahlstrom L, Ryan UM, et al. Bacterial community profiling highlights complex diversity and novel organisms in wildlife ticks. Ticks Tick-borne Dis. 2020;11:101407. https://doi. org/10.1016/j.ttbdis.2020.101407.

18. Loh SM: Identification and characterisation of microorganisms in Australian wildlife ticks. Doctoral dissertation. Murdoch University; 2018.

19. Old JM, Sengupta C, Narayan E, Wolfenden J. Sarcoptic mange in wombats - a review and future research directions. Transbound Emerg Dis. 2018;65:399-407. https://doi.org/10.1111/tbed.12770.

20. Hoogstraal H, Aeschlimann A. Tick-host specificity. Bull Soc Entomol Suisse. 1982;55:5-32.

21. Cunningham AA. Disease risks of wildlife translocations. Conserv Biol. 1996:10(2):349-53.

22. Lyles AM, Dobson AP. Infectious disease and intensive management: population dynamics, threatened hosts, and their parasites. J Zoo Wildl Med. 1993;5:315-26.

23. Roberts FHS. The Australian species of Aponomma and Amblyomma (Ixodoidea). Aust J Zool. 1953;1(1):111-61.
24. Laan B, Handasyde K, Beveridge I. Occurrence of the tick Haemaphysalis bancrofti Nuttall \& Warburton, 1915 in Victoria with additional data on its distribution and with scanning electron micrographs of life cycle stages. Proc R Soc Victoria. 2011;56:189.

25. Jackson J, Beveridge I, Chilton NB, Andrews RH. Distributions of the paralysis ticks Ixodes cornuatus and Ixodes holocyclus in southeastern Australia. Aust Vet J. 2007;85:420-4. https://doi.org/10.111 1/j.1751-0813.2007.00183.x.

26. Seddon HR. Diseases of domestic animals in Australia: arthropod infestations: (ticks and mites): together with a section on animals. Department of Health: Insects and Other Agents Harmful to Stock. Commonwealth of Australia; 1968.

27. Macalister A. On some species of parasites hitherto undescribed. 1871.

28. Roberts FHS. A systematic study of the Australian species of the genus Ixodes (Acarina: Ixodidae). Aust J Zool. 1960;8(3):392-486.

29. Vilcins IME, Old JM, Deane E. Molecular detection of Rickettsia, Coxiella and Rickettsiella DNA in three native Australian tick species. Exp Appl Acarol. 2009:49:229-42. https://doi.org/10.1007/s10493-009-9260-4.

30. Barker SC, Walker AR. Ticks of Australia. The species that infest domestic animals and humans. Zootaxa. 2014;3816:1-144. https://doi.org/10.11646 /zootaxa.3816.1.1.

31. Roberts FHS. Australian ticks. 1970

32. Egan S: Profiling the bacterial microbiome of ticks that parasitise bandicoots in Australia. Doctoral dissertation. Murdoch University; 2017.

33. QGIS Development Team 2020. QGIS geographic information system. Open Source Geospatial Foundation Project. http://qgis.osgeo.org. Accessed 06 Jan 2020.

34. ICSM (2018) Geocentric Datum of Australia 2020 technical manual, version 1.3. https://www.icsm.gov.au/sites/default/files/2020-01/GDA20 20\%20Technical\%20Manual\%20V1.3.pdf. Accessed Jan 2020.

35. Documentation QGIS 3.10. https://docs.qgis.org/3.10/en/docs/user_ manual/working_with_vector/vector_properties.html?highlight=point \%20displacement\#point-displacement-renderer. Accessed 15 Jan 2020.

36. Ravi RK, Walton K, Khosroheidari M. MiSeq: a next generation sequencing platform for genomic analysis. Disease gene identification: Springer; 2018. p. 223-32.

37. Xiang L, Pozniak B, Cheng TY. Bacteriological analysis of saliva from partially or fully engorged female adult Rhipicephalus microplus by nextgeneration sequencing. Antonie Van Leeuwenhoek. 2017;110 1:105-13; doi: https://doi.org/10.1007/s10482-016-0780-8.

38. Zhang J, Kobert K, Flouri T, Stamatakis A. PEAR: a fast and accurate Illumina Paired-End reAd mergeR. Bioinformatics. 2014;30:614-20. https:// doi.org/10.1093/bioinformatics/btt593.

39. Caporaso JG, Kuczynski J, Stombaugh J, Bittinger K, Bushman FD, Costello EK, et al. QIIME allows analysis of high-throughput community sequencing data. Nat Methods. 2010;7:335-6. https://doi.org/10.1038/nmeth f.303.

40. Edgar RC. Search and clustering orders of magnitude faster than BLAST. Bioinformatics. 2010;26:2460-1. https://doi.org/10.1093/bioinformatics/ btq461.

41. Edgar RC. UPARSE: highly accurate OTU sequences from microbial amplicon reads. Nat Methods. 2013;10(10):996-8. https://doi.org/10.1038/ nmeth.2604.

42. Fox J, Bouchet-Valat M, Andronic L, Ash M, Boye T, Calza S, et al. Package Rcmdr. 2020.

43. Team R: RStudio: integrated development for R. 1.2.5033 edn. RStudio, Boston, MA. 2019.

44. Oksanen J, Blanchet FG, Friendly M, Kindt R, Legendre P, McGlinn $D$, et al. vegan: community ecology package. $R$ package version. 2019;2(5-6):2019.

45. McMurdie PJ, Holmes S. phyloseq: an R package for reproducible interactive analysis and graphics of microbiome census data. PLOS ONE. 2013;8:e61217. https://doi.org/10.1371/journal.pone.0061217.

46. Smales L. Parasites of the wombat Vombatus ursinus from the Gippsland region, Victoria. Trans R Soc S Aust. 1987;111:129-30.

47. Skerratt LF. Diseases and parasites of the common wombat Vombatus ursinus in the Healesville area of Victoria. New York: Surrey Beatty \& Sons; 1998.

48. Skerratt LF, Skerratt JHL, Banks S, Martin RW, Handasyde K. Aspects of the ecology of common wombats (Vombatus ursinus) at high density on pastoral land in Victoria. Aust J Zool. 2004:52(3):303-30. 
49. Gemmell RT, Cepon G, Green PE, Stewart NP. Some effects of tick infestations on juvenile northern brown bandicoot (Isoodon macrourus). J Wildl Dis. 1991;27(2):269-75.

50. Spencer AJ, Canfield PJ. Haematological characterisation of heavy tick infestation in koalas (Phascolarctos cinereus). Compar Haematol Int. 1993;3(4):225-9.

51. Roberts FHS. Further observations on the Australian species of Aponomma and Amblyomma with descriptions of the nymphs of Amblyomma moreliae (L. Koch) and Amb. loculosum Neumann (Acarina: Ixodidae). Aust J Zool. 1964;12:288-314.

52. Hammer JF, Emery D, Bogema DR, Jenkins C. Detection of Theileria orientalis genotypes in Haemaphysalis longicornis ticks from southern Australia. Parasites Vectors. 2015;8:229. https://doi.org/10.1186/s13071-015-0839-9.

53. Bremner KC. Observations on the biology of Haemaphysalis bispinosa Neumann (Acarina: Ixodidae) with particular reference to its mode of reproduction by parthenogenesis. Aust J Zool. 1959;7(1):7-12.

54. Hoogstraal H, Roberts FH, Kohls GM, Tipton VJ. Review of Haemaphysalis (Kaiseriana) longicornis Neumann (resurrected) of Australia, New Zealand, New Caledonia, Fiji, Japan, Korea, and northeastern China and USSR, and its parthenogenetic and bisexual populations (Ixodoidea, Ixodidae). J Parasitol. 1968;78:1197-213.

55. Sun J, Liu Q, Lu L, Ding G, Guo J, Fu G, et al. Coinfection with four genera of bacteria (Borrelia, Bartonella, Anaplasma, and Ehrlichia) in Haemaphysalis longicornis and Ixodes sinensis ticks from China. Vector-Borne Zoon Dis. 2008;8:791-5. https://doi.org/10.1089/vbz.2008.0005.

56. James MP, Saunders BW, Guy LA, Brookbanks EO, Charleston WA, Uilenberg G. Theileria orientalis, a blood parasite of cattle. First report in New Zealand. N Z Vet J. 1984;32:154-6. https://doi.org/10.1080/00480 169.1984.35103.

57. Stewart NP, Uilenberg G, De Vos AJ. Review of Australian species of Theileria, with special reference to Theileria buffeli of cattle. Trop Anim Health Prod. 1996;28(1):81-90.

58. Bagnall BG, Doube BM. The Australian paralysis tick /xodes holocyclus. Aust Vet J. 1975;51(3):159-60.

59. Stone BF, Binnington KC, Gauci M, Aylward JH. Tick/host interactions for Ixodes holocyclus: role, effects, biosynthesis and nature of its toxic and allergenic oral secretions. Exp Appl Acarol. 1989;7(1):59-69.

60. Moorhouse DE. Observations on copulation in Ixodes holocyclus Neumann and the feeding of the male. J Med Entomol. 1966;3(2):168-71.

61. Vilcins IME, Kosoy M, Old JM, Deane EM. Bartonella-like DNA detected in Ixodes tasmani ticks (Acari: Ixodida) infesting koalas (Phascolarctos cinereus) in Victoria Australia. Vector-Borne Zoon Dis. 2009;9:499-503. https://doi.org/10.1089/vbz.2008.0132.

62. Vilcins IME, Old JM, Deane E. Detection of a Hepatozoon and spotted fever group Rickettsia species in the common marsupial tick (Ixodes tasmani) collected from wild Tasmanian devils (Sarcophilus harrisii) Tasmania. Vet Parasitol. 2009;162:23-31. https://doi.org/10.1016/j.vetpa r.2009.02.015.

63. Izzard L, Graves S, Cox E, Fenwick S, Unsworth N, Stenos J. Novel rickettsia in ticks, Tasmania, Australia. Emerg Infect Dis. 2009;15:1654-6. https://doi. org/10.3201/eid1510.090799.

64. Vilcins IME, Old JM, Deane EM. Detection of a spotted fever group Rickettsia in the tick Ixodes tasmani collected from koalas in Port Macquarie Australia. J Med Entomol. 2008;45(4):745-50.

65. Weilgama DJ. Transmission of Theileria peramelis Mackerras, 1959 by Ixodes tasmani. Parasite lives: papers on parasites, their hosts and their associations to honour JFA Sprent/edited by Mary Cremin, Colin Dobson and Douglas E Moorehouse. 1986.

66. Moorhouse DE. The accumulation of microfilariae beneath the sites of attachment of Ixodes tasmani. Trans R Soc Trop Med Hyg. 1969;63:22.

67. Burnard D, Weaver H, Gillett A, Loader J, Flanagan C, Polkinghorne A. Novel Chlamydiales genotypes identified in ticks from Australian wildlife. Parasites Vectors. 2017;10:46. https://doi.org/10.1186/s13071-017-1994-y.

68. Stewart NP, Devos AJ, Shiels IA, Jorgensen WK. Transmission of Theileria buffeli to cattle by Haemaphysalis bancrofti fed on artificially infected mice. Vet Parasitol. 1989;34(1-2):123-7.

69. Swei A, Kwan JY. Tick microbiome and pathogen acquisition altered by host blood meal. ISME J. 2017;11:813-6. https://doi.org/10.1038/ismej .2016.152.

70. Panetta JL, Sima R, Calvani NED, Hajdusek O, Chandra S, Panuccio J, et al. Reptile-associated Borrelia species in the goanna tick (Bothriocroton undatum) from Sydney Australia. Parasites Vectors. 2017;10:616. https:// doi.org/10.1186/s13071-017-2579-5.

71. Lalzar I, Friedmann Y, Gottlieb Y. Tissue tropism and vertical transmission of Coxiella in Rhipicephalus sanguineus and Rhipicephalus turanicus ticks. Environ Microbiol. 2014;16(12):3657-68.

72. Tozer SJ, Lambert SB, Strong CL, Field HE, Sloots TP, Nissen MD. Potential animal and environmental sources of $Q$ fever infection for humans in Queensland. Zoon Public Health. 2014;61:105-12. https://doi. org/10.1111/zph.12051.

73. Bennett MD, Woolford L, Banazis MJ, O'Hara AJ, Warren KS, Nicholls PK, et al. Coxiella burnetii in western barred bandicoots (Perameles bougainville) from Bernier and Dorre Islands in Western Australia. Ecohealth. 2011;8:519-24. https://doi.org/10.1007/s10393-011-0729-3.

74. Cooper A, Barnes T, Potter A, Ketheesan N, Govan B. Determination of Coxiella burnetii seroprevalence in macropods in Australia. Vet Microbiol. 2012;155:317-23. https://doi.org/10.1016/j.vetmic.2011.08.023.

75. Cooper A, Stephens J, Ketheesan N, Govan B. Detection of Coxiella burnetii DNA in wildlife and ticks in northern Queensland Australia. VectorBorne Zoon Dis. 2013;13:12-6. https://doi.org/10.1089/vbz.2011.0853.

76. Ehounoud CB, Yao KP, Dahmani M, Achi YL, Amanzougaghene N, Kacou N'Douba A, et al. Multiple pathogens including potential new species in tick vectors in Cote d'Ivoire. PLOS Neglect Trop Dis. 2016;10:e0004367. https://doi.org/10.1371/journal.pntd.0004367.

77. Dumler JS, Bakken JS. Ehrlichial diseases of humans: emerging tick-borne infections. Clin Infect Dis. 1995;20(5):1102-10.

78. Stuen S, Granquist EG, Silaghi C. Anaplasma phagocytophilum-a widespread multi-host pathogen with highly adaptive strategies. Front Cell Infect Microbiol. 2013;3:31. https://doi.org/10.3389/fcimb.2013.00031.

79. Gordon DM, Cowling A. The distribution and genetic structure of Escherichia coli in Australian vertebrates: host and geographic effects. Microbiology. 2003;149:3575-86. https://doi.org/10.1099/mic.0.26486-0.

80. Kaper JB, Nataro JP, Mobley HLT. Pathogenic Escherichia coli. Nat Rev Microbiol. 2004;2(2):123-40.

81. Rupan R, Jennison AV, Smith HV, Cobbold RN. Carriage of Shiga-toxigenic Escherichia coli by native marsupials in Australia. Vet Microbiol. 2012;155:279-83. https://doi.org/10.1016/j.vetmic.2011.08.013.

82. Ceraul SM, Sonenshine DE, Hynes WL. Resistance of the tick Dermacentor variabilis (Acari: Ixodidae) following challenge with the bacterium Escherichia coli (Enterobacteriales: Enterobacteriaceae). J Med Entomol. 2002;39(2):376-83.

83. Sonenshine DE, Ceraul SM, Hynes WE, Macaluso KR, Azad AF. Expression of defensin-like peptides in tick hemolymph and midgut in response to challenge with Borrelia burgdorferi, Escherichia coli and Bacillus subtilis. Ticks and tick-borne pathogens: Springer; 2003. p. 127-34.

84. Andreotti R, de León AAP, Dowd SE, Scoles GA. Assessment of bacterial diversity in the cattle tick Rhipicephalus (Boophilus) microplus through tag-encoded pyrosequencing. BMC Microbiol. 2011;11:6.

85. Murrell A, Dobson SJ, Yang X, Lacey E, Barker SC. A survey of bacterial diversity in ticks, lice and fleas from Australia. Parasitol Res. 2003;89:32634. https://doi.org/10.1007/s00436-002-0722-4.

86. Swe PM, Reynolds SL, Fischer K. Parasitic scabies mites and associated bacteria joining forces against host complement defence. Parasite Immunol. 2014;36:585-93. https://doi.org/10.1111/pim.12133.

87. Taponen S, Supre K, Piessens V, Van Coillie E, De Vliegher S, Koort JM. Staphylococcus agnetis sp. nov., a coagulase-variable species from bovine subclinical and mild clinical mastitis. Int J Syst Evol Microbiol. 2012;62:615. https://doi.org/10.1099/ijs.0.028365-0.

88. Al-Rubaye AA, Couger MB, Ojha S, Pummill JF, Koon JA 2nd, Wideman RF Jr, et al. Genome analysis of Staphylococcus agnetis, an agent of lameness in broiler chickens. PLoS ONE. 2015;10:e0143336. https://doi.org/10.1371/ journal.pone.0143336.

89. Hoedemaekers A, Schulin T, Tonk B, Melchers WJ, Sturm PD. Ventilatorassociated pneumonia caused by Dolosigranulum pigrum. J Clin Microbiol. 2006;44:3461-2. https://doi.org/10.1128/JCM.01050-06.

90. Lecuyer H, Audibert J, Bobigny A, Eckert C, Janniere-Nartey C, Buu-Hoi $A$, et al. Dolosigranulum pigrum causing nosocomial pneumonia and septicemia. J Clin Microbiol. 2007;45:3474-5. https://doi.org/10.1128/ JCM.01373-07.

91. Gobeli Brawand S, Cotting K, Gomez-Sanz E, Collaud A, Thomann A, Brodard I, et al. Macrococcus canis sp. nov., a skin bacterium associated 
with infections in dogs. Int J Syst Evol Microbiol. 2017;67:621-6. https:// doi.org/10.1099/ijsem.0.001673.

92. Rurangirwa FR, Teitzel CA, Cui J, French DM, McDonough PL, Besser T. Streptococcus didelphis sp. nov., a Streptococcus with marked catalase activity isolated from opossums (Didelphis virginiana) with suppurative dermatitis and liver fibrosis. Int J Syst Evol Microbiol. 2000;50:759-65. https://doi.org/10.1099/00207713-50-2-759.

93. Vieira V, Teixeira LM, Zahner V, Momen H, Facklam RR, Steigerwalt AG, et al. Genetic relationships among the different phenotypes of Streptococcus dysgalactiae strains. Int I Syst Evol Microbiol. 1998;48(4):1231-43.

94. Abdullah HH, El-Molla A, Salib FA, Allam NA, Ghazy AA, Abdel-Shafy S. Morphological and molecular identification of the brown dog tick Rhipicephalus sanguineus and the camel tick Hyalomma dromedarii (Acari: Ixodidae) vectors of rickettsioses in Egypt. Vet World. 2016;9:1087-101. https://doi.org/10.14202/vetworld.2016.1087-1101.
95. Lv J, Wu S, Zhang Y, Zhang T, Feng C, Jia G, et al. Development of a DNA barcoding system for the Ixodida (Acari: Ixodida). Mitochondrial DNA. 2014;25:142-9. https://doi.org/10.3109/19401736.2013.792052.

96. Merhej V, Raoult D. Rickettsial evolution in the light of comparative genomics. Biol Rev Camb Philos Soc. 2011;86:379-405. https://doi. org/10.1111/j.1469-185X.2010.00151.X

97. Viggers KL, Lindenmayer DB, Spratt DM. The importance of disease in reintroduction programmes. Wildl Res. 1993;20(5):687-98.

\section{Publisher's Note}

Springer Nature remains neutral with regard to jurisdictional claims in published maps and institutional affiliations.
Ready to submit your research? Choose BMC and benefit from:

- fast, convenient online submission

- thorough peer review by experienced researchers in your field

- rapid publication on acceptance

- support for research data, including large and complex data types

- gold Open Access which fosters wider collaboration and increased citations

- maximum visibility for your research: over $100 \mathrm{M}$ website views per year

At BMC, research is always in progress.

Learn more biomedcentral.com/submissions 